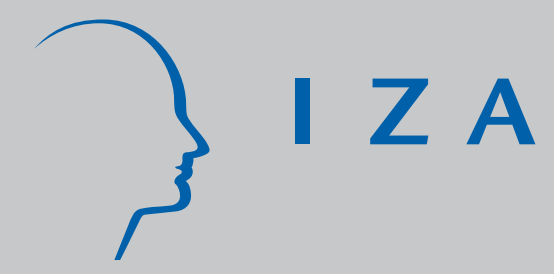

IZADP No. 1993

Do Poor Children Become Poor Adults? Lessons from a Cross Country Comparison of Generational Earnings Mobility

Miles Corak

March 2006 


\title{
Do Poor Children Become Poor Adults? Lessons from a Cross Country Comparison of Generational Earnings Mobility
}

\author{
Miles Corak \\ Statistics Canada and IZA Bonn
}

Discussion Paper No. 1993

March 2006

IZA
P.O. Box 7240
53072 Bonn
Germany

Phone: +49-228-3894-0

Fax: +49-228-3894-180

Email: iza@iza.org

Any opinions expressed here are those of the author(s) and not those of the institute. Research disseminated by IZA may include views on policy, but the institute itself takes no institutional policy positions.

The Institute for the Study of Labor (IZA) in Bonn is a local and virtual international research center and a place of communication between science, politics and business. IZA is an independent nonprofit company supported by Deutsche Post World Net. The center is associated with the University of Bonn and offers a stimulating research environment through its research networks, research support, and visitors and doctoral programs. IZA engages in (i) original and internationally competitive research in all fields of labor economics, (ii) development of policy concepts, and (iii) dissemination of research results and concepts to the interested public.

IZA Discussion Papers often represent preliminary work and are circulated to encourage discussion. Citation of such a paper should account for its provisional character. A revised version may be available directly from the author. 


\section{ABSTRACT \\ Do Poor Children Become Poor Adults? Lessons from a Cross Country Comparison of Generational Earnings Mobility}

A cross country comparison of generational earnings mobility is offered, and the reasons for the degree to which the long run labour market success of children is related to that of their parents is examined. The rich countries differ significantly in the extent to which parental economic status is related to the labour market success of children in adulthood. The strength of these associations should not be interpreted as offering a target or menu for the conduct of policy. A framework for understanding the underlying causal process as well as the conception of equality of opportunity is reviewed as a guide for public policy.

JEL Classification: D31, I132, J62

Keywords: poverty, generational mobility

Corresponding author:

Miles Corak

Family and Labour Studies

24th Floor, R.H. Coats Building

Statistics Canada

Ottawa

Canada K1A 0T6

Email: miles.corak@statcan.ca

\footnotetext{
* This paper is a summary and extension of the introductory chapter in Corak (2004a), and much abridged versions of a first draft have been released as Corak (2005a, b). An earlier version was presented to the Colloque sur le devenir des enfants de familles défavourisées en France, Paris April 2004 and released in the associated conference proceedings as Corak (2004b). The earlier version was also presented to seminars at the UNICEF Innocenti Research Centre, the Department of Statistics, University of Florence, the IZA Bonn Germany and to the workshop on "The Welfare State in an International Perspective" organized by the CRISS (The Network for the Economics of the Welfare State) and the J. Monnet chair in European Macroeconomics at the University of Siena, Certosa di Pontignano, September 2004. Comments from participants at these forums are gratefully acknowledged. In addition I would also like to thank Anders Björklund, John Creedy, Maurizio Franzini, Christopher Jencks, Marco Mira d'Ercole, and an anonymous referee for their comments and feedback. Further comments are welcomed at the above email address. This paper is forthcoming in Research on Economic Inequality, Volume 13.
} 


\section{Do poor children become poor adults? \\ Lessons from a cross country comparison \\ of generational earnings mobility}

In the United States almost one half of children born to low income parents become low income adults. This is an extreme case, but the fraction is also high in the United Kingdom at four in ten, and Canada where about one-third of low income children do not escape low income in adulthood. In the Nordic countries, where overall child poverty rates are noticeably lower, it is also the case that a disproportionate fraction of low income children become low income adults. Generational cycles of low income may be common in the rich countries, but so are cycles of high income. Rich children tend to become rich adults. Four in ten children born to high income parents will grow up to be high income adults in the United States and the United Kingdom, and as many as onethird will do so in Canada. ${ }^{1}$

These facts motivate the two objectives of this paper. The first is to derive internationally comparable measures of the degree of generational mobility across the rich countries, and to offer a framework for understanding the differences between them. The second is to offer a framework for understanding the role of public policy in influencing these patterns. In particular, I hope to cast light on these issues by offering a review of the major findings of a literature dealing with the degree of generational

\footnotetext{
${ }^{1}$ The sources for the information in this paragraph are Björklund et al (2003), Corak and Heisz (1999), Dearden, Machin and Reed (1997), and Hertz (2004).
} 
earnings mobility in the rich countries, summarizing and extending the work presented in Corak (2004a).

The major focus is on illustrating a framework for thinking about generational income dynamics, and in this way highlighting the reasons for the degree to which the long run labour market success of children is related to that of their parents. Just how strong are these patterns? Is the advantage that high income parents pass on to their children due to money? Are the disadvantages faced by low income children the result of monetary poverty? There are a number of reviews summarizing the state of knowledge on these issues, most recently by Bruniaux and Galtier (2003), Jencks (2004), Mayer (2002), Solon (2002, 1999), and Swift (2002). This paper adds to the lessons drawn by these authors in explicitly offering a cross country comparison of the degree of generational earnings mobility, and suggesting that an appreciation of these differences can contribute to understanding the underlying process. If we understand the mechanisms determining generational mobility we can begin to think about whether policy makers should attempt to influence it and how they might do so.

I find that countries differ significantly in the extent to which family economic status is related to the labour market success of children in adulthood. At one extreme, about $40 \%$ of parental earnings advantage is passed on to children in France, and up to $50 \%$ in the United Kingdom and United States. At the other extreme children inherit less than $20 \%$ of any parental earnings advantage or disadvantage in Canada, Finland, and Norway, and Denmark. A good deal of care, however, is needed in interpreting these patterns, and while a case can be made to suggest that they offer a much needed indicator of social inclusion from the perspective of children, it is not clear they offer a target or 
menu for the conduct of policy. Two things are needed for this to be so: first, a sense of what equality of opportunity means, and second an understanding of the underlying causes.

I discuss both of these issues, but with respect to the latter the analysis suggests that if additional money plays an important role in determining generational earnings mobility then income transfer policies may influence this process; if it doesn't then there is a need to think more broadly and pay particular attention to what I will call investment policies.

2. The measurement of generational earnings mobility Much of economic analysis uses a simple empirical model to measure generational mobility in earnings or income. This is usually done in percentage, or equivalently logarithmic terms, and refers to the fraction of income differences between parents that on average is observed among their children in adulthood. For example, if the incomes of two sets of parents differ by 100 percent and the incomes of their children differ by 60 percent, the generational persistence of incomes is said to be 60 percent since six-tenths of the difference in parental income is passed on to the children. If $Y$ represents permanent income and $t$ is an index of generations, this way of thinking can also be captured by the following expression:

$$
\ln Y_{i, t}=\alpha+\beta \ln Y_{i, t-1}+\varepsilon_{i, t}
$$

In this equation the adult income (in natural logarithms) of family i's child, $\ln Y_{i, t}$, is expressed as the average adult income of the children of generation $t$, as represented by $\alpha$, plus two factors determining the deviation from this average: a fraction of parental 
permanent income $\left(\beta \ln Y_{i, t-1}\right)$ and other influences not associated with parental income $\left(\varepsilon_{i, t}\right)$.

The average income of generations will evolve through time, and it may be that many or all members of a generation will have incomes higher than what their parents had at a similar age in the past. This is captured in equation (1) by the value of $\alpha$. However, and just as importantly, the equation reflects the idea that an individual's income is nonetheless related to his or her parents' income. This is captured by the value of $\beta$, which represents the fraction of economic advantage that is on average transmitted across the generations. In other words, $\beta$ summarizes in a single number the degree of generational income mobility in a society. It is often referred to as the generational income elasticity, and could conceivably be any real number. A positive value would indicate generational persistence of incomes in which higher parental income is associated with higher child incomes; a negative number would indicate generational reversal of incomes in which higher parental income is associated with lower child incomes. In fact empirical studies in the rich countries have always found $\beta$ to lie between zero and one. If, as above, 60 percent of the difference in parental incomes were passed on to the children, $\beta$ would have the value of 0.6 . When $\beta$ is greater than zero but less than one there is some generational mobility of income, so that parents with incomes above (or below) the average will have children who grow up to have incomes above (or below) the average. However, the deviation from the average will not be as great in the children's generation. That this is the case in the rich economies should not be too surprising. Expected mobility is greater the lower the value of $\beta$, that is the more rapid regression to the mean. In the extreme with $\beta=0$ there is no relationship between parent 
and child outcomes and the expected outcome of a child is just the average income for all children regardless of parental income. ${ }^{2}$

Depending upon the degree of inequality in parental incomes, even small values of $\beta$ can confer substantial advantages to the children of the well off. For example, using data from the United States Harding, Jencks, Lopoo, and Mayer (2004) report that, in 1999, households with children under the age of 18 at the top income quintile had twelve times as much money (when corrected for household size) as those at the bottom quintile. The generational income elasticity directly translates this ratio into the economic advantage a child from the higher income family can expect to have in the next generation over one from the lower income family. ${ }^{3}$ For different values of $\beta$ this is:

\begin{tabular}{l|llllll}
$\beta$ & 0 & 0.2 & 0.4 & 0.6 & 0.8 & 1.0 \\
\hline $\begin{array}{l}\text { Income } \\
\text { Advantage }\end{array}$ & 1.0 & 1.64 & 2.70 & 4.44 & 7.30 & 12.0
\end{tabular}

With a generational elasticity as high as 0.6 , children born to the higher income parents can be expected to earn — that is, when $\hat{\varepsilon}_{i, t}=0$-almost four and half times as much as children born to the lower income parents. A four and a half fold income advantage is no small matter. Lower values of $\beta$ translate into smaller advantages. With a $\beta$ of 0.2 the advantage falls to about one and two thirds. This is still considerable, but it pales in comparison to the fact that the higher income parents started off earning 12 times the

\footnotetext{
${ }^{2}$ The discussion in this paragraph refers to mobility in terms of levels and not rank order, for which the correlation is the appropriate summary measure. To be more precise an elasticity of one implies complete generational persistence of incomes if the standard deviation of incomes for fathers and sons is the same and if $\alpha=1$. In this case the two statistics would be the same.

${ }^{3}$ This is derived by taking the antilog of equation (1.1) so that $Y_{i, t}=\exp (\alpha) \times \exp \left(\beta \ln Y_{i, t-1}\right)=\exp (\alpha)\left(Y_{i, t-1}\right)^{\beta}$ if $\varepsilon_{i, t}$ is ignored. This implies that the ratio of incomes for children from high income $(H)$ and low income (L) backgrounds is $Y_{H, t} / Y_{L, t}=\left(Y_{H, t-1} / Y_{L, t-1}\right)^{\beta}$, that is, the ratio of their parents' incomes raised to the $\beta$ power. The values in this table are simply 12 raised to power given by the alternative values of $\beta$.
} 
income of the lower income families, and implies that there will be virtually no association between the incomes of grandparents and their grandchildren.

There are important practical difficulties in undertaking cross country comparative analyses based upon this framework. Most notably the data requirements are stringent in the extreme, and indeed, the most significant way to advance knowledge in this field involves the development of appropriate data. Ideal data sets for the study of long-term processes, those playing out over the course of a generation or more, rarely exist. Researchers and practitioners often imagine the ideal data source as being a longstanding longitudinal survey that captures young people in their early years while still in the parental home, follows them through time, and eventually obtains information from them in adulthood. A survey of this sort must be based upon a representative sample of individuals and accurately measure both parental income as well as the adult income of children. The measures of parental income must represent the long term economic wellbeing of the family and the resources available to invest in children, not simply annual income for a limited number of years. There are many challenges in bringing such an ideal to fruition: maintaining the representative nature of the sample through long periods of time and the entire income distribution, and obtaining accurate reporting of incomes are but two, to say nothing of the necessarily long lags between implementation and release dates. Indeed, researchers using longitudinal data sources are often forced to tease results from rather small sample sizes. Data of this sort are often used in the study of generational dynamics in the United States, Germany, and the United Kingdom.

An important alternative worthy of more consideration is information from administrative sources. These data are collected as part of the conduct of a government 
program, like income taxation, and are linked through time into appropriate units of analysis. Many of the usual drawbacks of administrative data—-that the concepts measured and the units of analysis do not correspond to theoretical constructs, that the sample is not representative, and that only a limited number of co-variates are availableare not always applicable to studies of generational income dynamics, or at least are not insurmountable. Administrative data, which can offer samples measured in the tens-if not hundreds—of thousands, contain information on incomes much more accurate than available from household surveys, and may contain a surprising amount of supplementary information. The development of these data continues to represent an important way forward in the advancement of knowledge, and they have been used advantageously by analysts studying the Nordic countries and Canada. This research suggests that the development of administrative data for research purposes and their dissemination in a way that respects issues of confidentiality and privacy has offered an extremely cost and time effective way of promoting knowledge on generational issues in a number of countries.

All of this said, longitudinal data, from either survey or administrative sources, are not the only means of undertaking generational analysis. Researchers have made creative use of empirical methods to overcome limitations in the quality of available data. The most notable illustration involves the use of cross sectional surveys containing retrospective information. Obtaining information from a sample of adults on the incomes their parents earned decades in the past is fraught with difficulties and generally avoided by statistical agencies. It is, however, much easier to obtain retrospective information on parental education and occupation. This information can be used to estimate parental 
income. This has the advantage of correcting for some of the most common measurement error problems, but at the same time does not come without a cost in terms of potentially biased results. The nature and direction of these biases are understood, and this method opens up the possibility of examining the degree of generational income mobility in a comparable way when longitudinal are not available. Generational income dynamics have been studied in a number of countries in this way, notably France, the United Kingdom and a number of developing countries. Including retrospective information of this sort in more data sets would offer a cost effective way of more fully understanding generational dynamics in countries lacking longitudinal or administrative sources.

The use of information on parent incomes and the adult incomes of children cannot be done uncritically, and it is difficult to draw valid inferences about crosscountry differences in generational income mobility by comparing independently completed studies. Figure 1, for example, illustrates the extent of the diversity in the estimates, particularly in the case of the United States for which the number of studies in the literature is most numerous. In this case, the estimates range from less than 0.1 to over 0.6. This range is so wide as to make international comparisons entirely questionable. While the results may differ between and within countries for substantive reasons, they may also differ because of a host of data and methodological decisions made by researchers. These are now well known in this literature, having been clearly delineated by Atkinson, Maynard, Trinder (1983) and more formally through subsequent research by, for example, Jenkins (1987), Creedy (1988), Reville (1995), Solon (1989, 1992), Zimmerman (1992), and Grawe (2003, 2004). The first of these issues concerns the appropriate measurement of $Y_{i, t-1}$ in equation (1), parental 'permanent' income. It is 
on the basis of their long term earnings prospects that parents make long term decisions influencing the well being of their children, not simply on the basis of their current earnings. But this so-called 'permanent' income must be derived by the researcher from information available in the data set, often annual measures of income or earnings. This inevitably implies that it will be measured with error so that researchers actually observe $\tilde{Y}_{i, t-1}=Y_{i, t-1}+v_{i}$, where $v_{i}$ represents a transitory shock to income. It can be shown that the estimated coefficient $(\tilde{\beta})$ will differ from the true value according to a factor determined by the ratio of the variance of $v_{i}$ to that of $Y_{i, t-1}$ so that $\tilde{\beta}\left(1+\sigma_{v}^{2} / \sigma_{Y}^{2}\right)=\beta$. In other words, if no correction is made for measurement error there will be a tendency to attribute part of the temporary earnings fluctuations to generational mobility, the estimated coefficient will be an understatement of the true value. ${ }^{4}$ The common corrections include using an average of a number of annual measures of parental income in order to reduce the influence of transitory variations, or as alluded to above the prediction of permanent income using supplemental information on the determinants of parental income independent of child outcomes. The first approach will tend to understate the truth if the averaging is not over a long enough horizon, while the second will overstate it because parental characteristics like education and occupation are assumed to impact the earnings prospects of children entirely through their influence on parental income when in fact they also do so directly. Part the reason for the differences illustrated

\footnotetext{
${ }^{4}$ This takes as its starting point a view of the world in which parents are able to smooth their income over time and it is their permanent income that matters when investment decisions are made for their children's future, not the actual income they earned during the period the child was raised. Also it might be noted, as clarified by Solon (1989), that this measurement error is aggravated if the sample used is not representative of the underlying population of parents. If this is the case the sample variance understates the true variance, $\sigma_{Y}^{2}$, and the bias is larger as a result. It is important for this reason that samples be representative of the entire population.
} 
in Figure 1 has to do with differences in the manner and degree to which researchers obtain accurate estimates of permanent incomes.

The second measurement issue is a related concern associated with the age at which incomes are obtained for the parents. Individual annual incomes tend to rise rather steeply between the ages of 20 and 30, and then flatten out in the prime working years during the 40s, before declining during the 50s and 60s. This pattern is not identical across individuals and is subject to more variance at younger and older ages.

Consequently the importance of measurement error will vary depending upon the part of life cycle observed, being greatest for younger and older parents and likely lowest for those in their 40s. Grawe $(2004,2003)$ points out that a simple comparison of independently completed research published on the average degree of generational mobility reveals as much about the age of the parent as it does about substantive differences between countries. This is illustrated in Figure 2 for 26 estimates from the United States. Those studies based upon measures of income when the parent is 50 years of age or older yield much lower estimates of $\beta$ than those when the parent is between 45 and 50, which in turn are lower than those based on data for those in their early 40s. (The average estimate is 0.154 when fathers are on average 50 years or older, 0.406 when they are between 45 and 49 years, and 0.433 when they are younger than 45 on average.)

In short, the development of a set of comparable estimates across countries requires that the specifics of the study design be taken into account, particularly the extent and nature of corrections for measurement errors as well as the age at which parents are observed. This is not a simple task and my reading of the literature, detailed in the appendix, suggests the set of estimates presented with upper and lower bounds in 
Table 1. This information accounts roughly for the fact that results in the literature differ according to the extent measurement errors are corrected, and the point in the life cycle parental earnings are obtained. For comparative purposes the preferred estimates are based upon studies of father and son earnings, fathers being 40 to 45 years of age, and their earnings averaged over a ten year period. The details of the derivation are provided in the Appendix. Information on daughters and on other definitions of material resources is starting to become available in the literature but is still not as extensive as the fatherson relationship. Thus, the focus is on fathers and sons in order to maximize the number of countries for which comparisons can be made.

If these findings are correct they suggest, firstly, that there is a good deal of variation across the rich countries in the degree to which paternal earnings advantage is passed on to sons - by at least a factor of two from $20 \%$ or less to $40 \%$ or more—and, secondly, that in no country is the inherited parental advantage much lower than onefifth. The United States, the United Kingdom, and to a slightly lesser extent France, stand out as being the least mobile societies, with 40 to $50 \%$ of fathers' earnings advantage being passed on to sons. At the other extreme are Denmark, Norway, Finland, and Canada with about 15 to $20 \%$ of earnings advantage passed across generations, and in an intermediate position Germany and Sweden with about 30\%. Studies using a broader measure of parental resources, total family income for example, generally find higher values for $\beta$ than those based solely on paternal earnings.

3. The meaning of generational earnings mobility 
What exactly does this statistic mean? What accounts for the differences between countries? And how can this information be used as either a goal or as a tool for policy makers? I would like to suggest that it offers an overall indicator of social inclusion from the perspective of children. As such it can inform and lend a child perspective to discussions of social policy. At the same time I would also suggest that thinking of it as either a goal or target for the direction of policy, or for that matter a tool for the conduct of policy, is much more problematic. This requires, on the one hand, a clearer understanding of the meaning of equality of opportunity, and on the other hand a fuller appreciation of the causal processes determining the long term labour market success of children.

There has been a good deal of discussion about the appropriate indicators to gauge the degree of social inclusion in Europe. Atkinson, Cantillon, Marlier, and Nolan (2002) summarize the issues, present a set of underlying principles that good indicators should follow, and review a number of aggregate statistics to guide the European social agenda as reflected in the agreement of the Lisbon European Council. Many of these indicators are related to employment and labour market success, with measures of income inequality and poverty receiving a good deal of attention. However, one important limitation of this discussion, as recognized in recent discussions by the European Commission, is the lack of explicit indicators dealing with the well being of children (Commission of the European Communities 2003). One approach to meet this concern might be to include more specific age breakdowns of the existing set of indictors, including for example an indicator of child poverty as one obvious candidate. But a focus of this sort would miss the need to be future orientated and to gauge the extent to which 
children are able to become all that they could be regardless of their family background. What in effect is needed is a measure of the equality of opportunity in a society, meaning the extent to which children have equal options in life regardless of their family background.

At first glance it may well appear that $\beta$ offers just such a measure with reference to labour market success, or at least many casual observers have in the past looked to this statistic as an indicator of equality of opportunity. But, issues of measurement and timeliness aside, there is a sense in which the degree of parental income advantage passed on to children falls short of being an appropriate indictor for the conduct of social policy. This is because it is not clear from this number alone what an appropriate target for policy would be, nor is it immediately clear how it relates to the tools of policy and hence its conduct.

a. The meaning of equality of opportunity and a target for policy

Does equality of opportunity imply that the generational elasticity is zero, that there is no correlation between parent and child incomes? Roemer (2004) argues that equality of opportunity implies that inequities of outcome are indefensible when they are due to differential circumstances, but he recognizes at the same time that parents influence their children through a hierarchy of 'circumstances'. To paraphrase his research, these are three in number: (1) through social connections that facilitate access to education and jobs; (2) through family culture and investments that influence skills, beliefs and motivation; and (3) through the genetic transmission of ability. These are the successively broader fields—each corresponding to a successively broader definition of 
equality of opportunity—that policy makers could potentially seek to level. Roemer makes explicit that equating equality of opportunity with complete generational mobility implies that not only should the influence of social connections and also of family culture and investment be eliminated, but so should the genetic transmission of ability and the influence of family on the formation of preferences and goals among children. He suggests this is "a view that only a fraction of those who consider the issue would, upon reflection, endorse” (Roemer, 2004, p. 49) As such, this is a cautionary note to readers of generational income mobility studies. In other words, the view that the appropriate target for policy should be to eliminate entirely the income advantage that is passed on between parents and children — to aim for $\beta=0$ as a goal—would require a degree of intervention into the lives of children and families that the majority in most societies might find untenable. The amount of parental income advantage passed on to children consistent with equality of opportunity is not self-apparent. It requires a definition of the circumstances unacceptable as sources of labour market success, an understanding of the effectiveness of policy interventions, and recognition of the trade-offs between the gains in eliminating them and the losses in terms of other measures of welfare. ${ }^{5}$

Furthermore, changes in $\beta$ over time within a country, or for that matter differences between countries, may not offer unambiguous signals of improvement in the degree of equality of opportunity. Social or policy changes that clearly promote equality of opportunity for some groups may result in a tighter-not a weaker-tie between the overall average parent and child incomes. For example, in a study of the United States Mayer and Lopoo (2004) make the argument that depending upon the structure of society and the nature of labour markets, parental investments in children may have different

\footnotetext{
${ }^{5}$ These issues are also discussed in Jencks and Tach (2005).
} 
payoffs across gender. If traditional gender roles have become less binding then trends in the generational income elasticity may well differ for sons and daughters. In other words, the rates of return to parental investments differ by gender, and changes in the labour market opportunities for women during the post-war period have improved the rate of return for girls relative to boys. These changes are reflected in delays in marriage and higher employment rates for women. The authors find that the generational elasticity for women rose over most of the post-war period and only began to fall more recently, reflecting the fact that women from more privileged backgrounds were among the first cohorts to seize upon new opportunities. In this sense a rise in the elasticity reflects more, not less, equality of opportunity for some groups in society.

Blanden, Goodman, Gregg and Machin (2004) reach broadly similar conclusions in a study of trends in generational mobility in the United Kingdom. They examine differences in generational income mobility between children growing up in the 1960s and 1970s and those growing up a decade later. The authors begin by underscoring the fact that this was a period of widening wage and income disparities. It was also a period in which the educational attainments of the young increased significantly, but once again in a way that was of relatively greater benefit to those from higher income parents. They find that the generational income elasticity rose significantly between these two groups, even though they were born only 12 years apart. The changes in $\beta$ were such that the income advantage of having parents in the top fifth of the income distribution over having parents in the bottom fifth went from 20 percent to 40 percent in this short time. The authors relate these changes to the expansion of the university system. Differences in educational attainment account for almost one fifth of the change in $\beta$ for men and fully 
40 percent for women. By implication and in light of the findings of Mayer and Lopoo (2004) it would seem that women from higher income families were best positioned to capture the opportunities afforded by the education reforms.

In sum, there are subtleties in the interpretation of the overall average degree of generational mobility that suggest caution in using it as a target for policy. These require a finer understanding of the workings of families and the way in which parents influence their children, of the structure of labour markets, and how both family and markets interact with social policy to determine the degree of mobility. In short there is a need to appreciate the causal processes at work.

b. The causes of generational income mobility and a framework for policy

Equation (1) is more than simply the starting point for empirical analyses

producing a summary measure of generational mobility; it is also motivated by economic theory, specifically the model of Becker and Tomes (1979). Mulligan (1997, chapters 2 and 3) offers a clear exposition of this and other related economic models of generational income dynamics. A central point of the Becker-Tomes model is that income mobility across the generations and inequality within generations can be understood in a unified way by recognizing that parents both care about and are able to influence the earnings capacity of their children. As a result parents allocate their time and money between current consumption and investments in the human capital of their children, investments that will increase their future economic well being. Human capital is broadly defined to refer to those aspects of the child's earning potential that parents can influence. Certainly other things beyond parental control will determine a child's earnings, including market 
luck and inherited ability. Further, the degree to which these are passed on through the generations and the impact on earnings will in part be determined by social institutions. The distinction, however, is that these influences are not explicitly the domain of parental choice, and this is what makes human capital different. Human capital investment is often equated with monetary investments in education and particularly higher education, but it also means investments in the physical health of children as well as investments in their mental health and social development. Parental choices are determined by preferences and by constraints, and as such parents face a trade-off between current consumption and future consumption of the child. They can increase the child's consumption in the future by investing in the child's earnings capacity or by out-right income transfers. Their propensity to do so will be determined by their preferences and by the rate of return on these investments. $\beta$ is an amalgam of these two factors, but also of the degree to which other endowments from the family — its culture and family connections are two examples - are inherited by the children. The degree of inheritability of these endowments is also influenced by the structure of the society and markets into which children grow up and find their way. The greater the parental preference for the future, the greater the return to any investments, and the greater the inheritability of other aspects of family background important for earnings, the greater $\beta$.

Solon (2004) takes this perspective as a starting point to develop a framework for comparative analysis either over time within a country, or over space between different countries. Two important questions motivate his analysis: what is the role of the market in determining income mobility across the generations? what is the role of public policy? The first relates to the fact that there have been very significant changes in the returns to 
higher education in the United States and some other, though not all, rich economies since the late 1970s and early 1980s. The second issue has to do with the fact that the nature and amount of public investment in children has changed tremendously during the post-war era and varies just as much across countries. Solon shows that increases in the return to education will tighten the link between parent and child incomes, while increases in progressive public investments - those of relatively greater benefit to the less well off—will loosen it. Cross country differences in generational mobility could arise from any number of factors, but these offer the first two places to seek out an explanation.

Table 2 supplements information on the generational earnings elasticities highlighted earlier with measures of rewards and opportunities. One indicator of reward is the return to higher education, as given by the private internal rate of return to tertiary education. Cross country patterns in the private returns to university education and the generational earnings elasticity are illustrated in Figure 3. This graph offers a scatter plot between the estimates of $\beta$ and the private pre-tax internal rate of return for tertiary education for men (in 1999/2000) as measured by the OECD in their publication Education at a Glance. The three countries with rates of return higher than $10 \%$-the United States at $18.9 \%$, the United Kingdom at $18.1 \%$, and France at $13.3 \%$-are the only countries with generational earnings elasticities higher than 0.4 . The raw correlation between the two statistics is strongly positive at 0.882 . These rates of return are an important determinant of the overall level of cross-sectional inequality, and as a result this relationship underscores the theoretical point made by Solon that a more unequal society is associated with less generational mobility. 
At a slightly different level Mayer and Lopoo (2004) point out that differences in returns to higher education "do not change equality of opportunity per se, but they do change the social and economic costs of unequal opportunity." If parents in two countries invest the same amount in their children's schooling and everything else is the same. The country with the higher return to schooling would have higher inequality between affluent children and poorer children, if the former are more likely to attend university. In other words, if the effect of parental income on their children's schooling is the same in the two countries, but the returns to schooling are higher in one than in the other, the effect of parental income on children's income will also be higher. This is what the data in Figure 3 are revealing. This said it may also be the case that countries with higher rates of return also have very different structures and policies in place in terms of access to higher education, one of the reasons for elevated rates of return being restrictions in the supply of university graduates.

This raises the question of differences in opportunity, of the extent to which children from higher income families are more likely to capitalize on the rewards available to higher education. Thus, the second factor likely to explain cross country differences in the degree to which parental income advantage is passed on has to do with differences in the relative benefit of investments—-both private and public—-to children from rich and from poor backgrounds. Table 2 offers one possible measure of this progressivity, the gradient between the cognitive abilities of children and the education level of their parents. Esping-Andersen (2004, Table 1) calculates this indicator using test score data from the International Adult Literacy Survey for a group of men in their 30s and their fathers' education. This information is available for seven of the countries under 
study, and the relationship with the generational earnings elasticity is illustrated in Figure 4. Again there is a very strong positive relationship between this variable and the generational earnings elasticity, with the raw correlation between the two statistics being 0.856. Germany is the only significant outlier in the graph.

This pattern reflects differences in the inequality of private and public investment in children. If the degree of income inequality is higher in one country than another it might be reasonable to expect that not only will the rewards of a given level of investment be higher, but also the level and distribution of investment in children. A country with more income inequality might also have more inequality in the investments that rich and poor parents can make in their children, and hence a lower degree of generational income mobility. But as Solon (2004) stresses the degree to which this is so will also depend upon how progressive public policy is, that is the degree to which children from less advantaged backgrounds disproportionately benefit from public programs. Mayer and Lopoo (2004) point out that under certain circumstances universal government programs can reduce the investment gap between rich and poor children. If the first dollar of investment creates the greatest increase in the well-being of the child, then when institutions outside the family invest equally in all children poor children are likely to gain more than affluent children. Indeed, the great promise of government investment in the expansion of universal education and increased access to higher education during the post war period was that it would flatten out gradients of this sort. Esping-Andersen's data suggest that there are still very large differences in the extent to which this has been done in the welfare states of the rich countries, and as such offers an 
important hint as to why countries differ in the degree to which economic advantage is passed on between parent and child.

As such these two explanations open up two distinct windows for the conduct of public policy: policies relating to the structure of labour markets and degree of inequality; policies dealing with the functioning of families, the incidence of public expenditures, and early childhood investment. In what follows I shall refer to these under the headings of income transfer policies and investment policies.

\section{Income transfer policies}

The generational consequences of income transfer policies can be framed in terms of their traditional role as schemes of redistribution or even as insurance against unexpected income loss. For example, a shock to the incomes of parents, either positive or negative, could persist for generations depending upon the value of $\beta$ so that children through no fault of their own could face very different earnings prospects as a result of events decades in the past. Social policies and redistributive taxes might be depicted as narrowing the gap between the incomes of parents so that the incomes of children converge to the mean more quickly, as for example in Figure 5. Or to cite the earlier example, if the difference in income between high and low income families in the United States was six rather than 12 , with $\beta=0.6$ the relative difference between the adult outcomes of children from these families would be less than three rather than approaching 4.5 .

This is a very appealing interpretation of how transfer programs might work since it implies they address two issues at once: reducing inequality and child poverty in the 
present, while at the same time reducing inequities in the future. This kind of rationale is often heard by governments adopting explicit targets for the reduction of child poverty: the goal of reducing child poverty being legitimized by the future benefits for children and society at large. But this interpretation makes two related assumptions, both based on the view that the relationship between parent and child incomes is causal. The first assumption is that money is perfectly fungible, that a dollar has the same influence on children regardless of its source. The second is that a stable linear relationship characterizes the parent-child relationship across the entire income distribution. These assumptions are not necessarily supported in the literature. In other words equation (1) may be a parsimonious way of summarizing the overall degree of generational mobility in a society, but it does not offer a menu for the conduct of income transfer policies. Consider, first, the issue of whether an extra dollar in the hands of parents will have the same impact on the adult prospects of children regardless of its source. There is evidence, at least from North America, to suggest that this is not in fact the case with Corak and Heisz (1998), Hill and Duncan (1987), Mayer (1997) finding that the presence of transfer income is associated with lower adult earnings of children, while income from assets and earnings—-holding constant the overall amount—being associated with higher earnings. It is sometimes argued that parental participation in transfer programs increases the likelihood that children will be less engaged in the labour market and also rely on state support when they reach adulthood. From this perspective transfer programs somehow prevent the development of self-sufficiency and perpetuate a generational cycle of poverty. Page (2004), for example, notes that so-called 'culture of poverty' arguments of this kind formed, to some degree, the backdrop for the 1996 reform of the welfare 
system in the United States. Theorists have offered different rationale for such arguments. One deals with preferences. For example, living in a family that relies on welfare may erode any stigma attached to the receipt of payments and cause the child to view the program as a legitimate income source. Another argument deals with perceptions or information. Living in a family relying on welfare gives the child information about the program and its rules and thereby makes it easier to collect in turn. (One can also imagine these mechanisms working in the opposite way for children whose parents are actively engaged in the labour market, or adopting future orientated actions like saving.) These theories are rarely rigorously tested in empirical research, which focuses on the comparatively simpler task of estimating the correlations in, for example, welfare receipt between parent and child.

But nonetheless generational correlations in reliance on transfer programs can be very high. Using US data up to 1993 Page (2004) finds that about 47 percent of women whose mothers received welfare went on to also rely on the program at least once, compared with 16 percent of those whose mothers did not use the program. These estimates imply a correlation of just over 0.3 in the use of welfare across the generations. Those who believe that some significant part of this is causal might argue that the appropriate generational view of transfer policies is that in Figure 6 in which two distinct relationships are depicted, based upon different values for an unobserved characteristic that leads one group of parents to have lower average incomes and than another. The argument would be that transfer programs are the cause of the lower relationship as they lead to a different level of labour market engagement among children for a given level of parental income. If this is the case policy makers need to design income support 
programs in a way that encourages or at least does not deter from active labour market engagement across the generations.

But even if income transfers do not play a causal role there is a need to reexamine the assumption that there is a single, stable, linear relationship between parent and child earnings across the entire income distribution. If two distinct groups of this sort exist then transferring money income from one to the other will do little to improve advantage in the next generation: the two groups are regressing to very different average incomes even if the slope of the two relationships is the same. In this sense more than money matters for the long run labour market success of children, though these other factors may be correlated with the level of financial resources. The evidence for this perspective relates to findings in the literature that the relationship between parent-child outcomes is not linear. Using information from the United States Hertz (2004) and Hyson (2003) both find that $\beta$ changes over the course of the income distribution, being close to zero for those with parents in the bottom 5 to $10 \%$ of the income distribution, and then rising. This implies that an extra dollar to these lowest income families will not change the earnings prospects of children at all. Corak and Heisz (1999) find a similar pattern but also note that after rising over the lower half of the income distribution $\beta$ then falls over the upper half. That Hertz and Hyson do not find exactly the same pattern in the upper part of the distribution would be consistent with the fact that they use survey data that might suffer from under-reporting of high incomes, while Corak and Heisz rely on administrative information with more complete coverage and much large sample sizes.

This roughly S-shaped pattern in the relationship between parent and child incomes uncovered in Corak and Heisz (1999) implies that $\beta$ is low for low income 
families, highest for middle income families, and low again for upper income families. This non-linearity can be interpreted as the result of an unobserved variable not controlled for in the estimation of a simple linear model of regression to the mean. This is consistent with a mixture of two different groups as depicted in Figure 6. Imagine that there are two types of families making up the overall population, for the sake of reference call them Type I families and Type II families. The first group has on average lower income and the children from these families have on average lower earnings prospects; the second group has on average higher income and the children from these families have on average higher earnings prospects. To use the parlance of equation (1) both groups may in fact have the same $\beta$, but they differ in their value of $\alpha$. If an analyst were not aware of the differences between them and estimated equation (1) for the entire population, in effect ignoring the fact that $\varepsilon_{i, t}$ is positively correlated with $Y_{i, t-1}$, then the estimate obtained of $\beta$ would be higher than the true value for either group. This is the explanation Hertz (2004) offers for the relatively high estimated $\beta$ in the United States. In his study the two groups are distinguished by race. But this sort of explanation would also fit the findings of Corak and Heisz (1999) for Canada, a society with less racial demarcation and with a much lower overall estimate of $\beta$.

The Corak and Heisz paper offers the most reliable examination of non linear patterns in the literature because of the large sample size (in the neighbourhood of 50,000 observations), and because the method they use involves a series of piece wise estimates over the course of the entire earnings distribution and does not impose strong parametric assumptions. An interpretation of their findings is offered in Figure 7, with the S-shape curve characterizing the pattern they uncover. In the lower part of the parental income 
distribution the estimation sample is dominated by Type I families and $\hat{\beta}$ is small and close to the true value. Over the lower half of the distribution $\hat{\beta}$ rises because Type II families increasingly contribute to the estimation sample. The estimated $\beta$ reaches its maximum in the middle of the distribution where the two types of families both contribute significantly to the sample used in the estimation, but it begins to fall in the upper half of the distribution as the contribution of Type I families falls off. At higher income levels Type II families dominate to a greater and greater degree with the result that $\hat{\beta}$ falls, approaching the true value for these families.

All of this is to say that policy makers should be cautious about adopting the view that income transfer policies, whatever their value in battling child poverty in the here and now, offer a way of breaking a generational cycle of poverty. This puts the onus on understanding the non-monetary factors that determine the outcomes of children, and stresses that generational cycles in poverty necessarily raise concerns about investments in children.

\section{Investment Policies}

An alternative framework for public policies geared to promoting generational mobility might be referred to as 'Investment Policies'. Increasingly observers concerned with the welfare of children are seeking to re-cast the welfare state into a scheme that will not only insure families against new sets of risks, but also invest in the future well being of its youngest citizens. Gøsta Esping-Andersen (2004, 2002) puts forward this view by noting that historically the investment role for public policy has been framed in terms of the expansion of universal primary and secondary education, and the promotion of access to 
tertiary education. In other words, the major policy thrust of the post-war era addressed to equality of opportunity has been increases in the access to higher and higher levels of schooling. This is a direction that should not be ignored, but he argues that the marginal benefits for public policy of continuing to focus on the monetary resources of parents, their investments in the schooling of their children, and monetary outcomes in the next generation, may have reached its limit in some countries.

For one thing societies vary a good deal in the levels of public spending for education and the relationship with the degree of generational mobility is not a simple one. This is illustrated in Figure 8, which plots the generational earnings elasticities against per pupil education expenditures (measured in PPP adjusted US dollars). The raw correlation in these data is rather weak at -0.062 , but this driven by the United States with very high levels of spending but also a very high elasticity. If this country is omitted from the calculation the correlation becomes -0.701 . Finland is also an outlier. For example, the United Kingdom and Finland both spend relatively low and similar amounts per student— $\$ 5,592$ and $\$ 6,003$ — but are characterized by very different degrees of mobility. These outliers illustrate that it is not just further changes in the overall spending on education that matter, but the structure of the system and the cognitive capacities of children permitting them to take advantage of the available opportunities. In particular, as Esping-Andersen (2004) and UNICEF (2002) point out, a system based on early tracking is detrimental to equality of opportunity, but it is those children with high levels of cognitive skills that will be able to take most advantage of whatever systems are in place.

In an analysis of data from the International Adult Literacy Survey and the Programme for International Student Assessment that includes Canada, the United States, 
the United Kingdom, Sweden, Norway, Denmark, Germany, and the Netherlands, Esping-Andersen (2004) shows first, that cognitive skills are an important determinant of long-run earnings; second, that they are only loosely correlated with educational attainment; and third, that cognitive performance is more closely related to the 'cultural capital,' or more broadly put the parenting style of the family, than it is to its material wealth. The inheritance of education, occupation and income is influenced in the first instance by the impact parents have on a child's cognitive performance, and-as illustrated in Figure 4—societies leveling the playing field with respect to these circumstances have had the most success in promoting generational mobility. As a result he argues that research and policy should focus on the family, and particularly the role played in the development of cognitive abilities among children. The important window of opportunity is during the early years, up to about five years of age. This meshes very much with developments in the science of early brain development. The idea is that the stimulation infants and young children receive from their environment influences their neural development and will ultimately define the outer limits of their capabilities. Children raised in families at the high end of the socioeconomic scale are more likely to be exposed to a stimulating environment and set upon an advantageous path in life with respect to health, cognitive development and social skills. If the brain does not receive the requisite environmental stimulation at certain critical periods, the window of opportunity closes and development fails to occur. This so-called "neural sculpting” occurs at different times for different brain functions, but timing is important. The point is that this process establishes the "initial conditions" of a life and sets the individual down a particular pathway, a pathway in which a series of 
cumulative experiences may set further constraints or present further opportunities. Keating and Hertzmann (1999) for example have put forward this view and suggest that the series of steps leading through important transitional periods in life look something like this: socio-economic circumstances early in life (and even in the pre-natal period) $\rightarrow$ birth weight and cognitive/social/emotional development $\rightarrow$ readiness to learn $\rightarrow$ language development $\rightarrow$ behavioral problems in school and educational achievement $\rightarrow$ mental well-being in adulthood $\rightarrow$ labour market success and job characteristics $\rightarrow$ stress, disability, absenteeism. Gradients of the sort described by equation (1) for the relationship between incomes in fact appear at each of these steps because they have their roots in early childhood and the individual's cumulative experience up to that point. Someone born to parents with low income entertains a higher risk of less successfully transiting through these stages and of ending up in a precarious labour market situation, which in turn diminishes his or her capacity for positive parenting. This raises the odds of a generational cycle of poverty, but money is as much the result as the cause of the vicious circle.

This is a hard theory to prove for the simple reason that the information requirements are very demanding. But Esping-Andersen (2004) notes that cognitive abilities are much more unequally distributed in some societies than others. Further, the degree of this inequality is strongly and positively correlated with the degree to which parental education is linked with the cognitive performance of children. Societies in which parental education is closely related to child cognitive outcomes are also societies in which these outcomes are less equally distributed. Understanding the reasons for this is important in setting the appropriate direction for public policy, and should be a priority 
for research. He argues that there are basic educational reforms that could be pursueddelaying or abolishing tracking, standardizing curricula, and extra support for less privileged children—but, on the whole, this perspective suggests that attention should shift to the family. In his view, the appropriate policy will involve more than simply offering financial support to low income families, to include the public provision of social services. Universal access to affordable day care permits mothers to work and explains the absence of child poverty in the Nordic countries. When coupled with the appropriate school setting and organized after school activities this shifts the source of cognitive stimulation from parents to social institutions, and begins to ultimately offset inequities in long-run outcomes. But this still leaves very much open how effective publicly provided early childhood education policies can be, a matter that would have to be addressed before specific policy recommendations could be made.

\section{Conclusion}

The major objectives of this paper are to summarize a simple framework used in analyses of generational income dynamics, and to highlight the major findings from the literature by focusing on cross-country comparisons. The rich countries in fact differ significantly in the degree of earnings mobility between fathers and sons. The United Kingdom, the United States, and to a slightly lesser extent France, are the least mobile countries with 40 to $50 \%$ of the earnings advantage high income young adults have over their lower income counterparts being associated with the fact that they were the children of higher earning parents. In none of the OECD countries under study is this relationship entirely 
eliminated, falling to about $20 \%$ or a little less in Canada, Finland, Norway, and Denmark.

Statistics of this sort offer an overall indicator of how families, labour markets and public policy interact to determine the long run labour market success of children. They are a forward looking measure of the extent to which the life chances of children are tied to their family background, and as such offer a much needed child-focused measure of social inclusion. On the other hand, these statistics offer neither a target for policy, nor a menu for policy choices. This requires a clear understanding of what equality of opportunity means, and of the causal processes determining generational dynamics. Drawing from recent research I point out that equality of opportunity may have three distinct meanings depending upon the extent to which public policy equalizes the influence parents have on their children, but that it is very likely that in no society would a policy maker find support for entirely eliminating the relationship between parent and child incomes.

The rewards to higher skilled / higher educated individuals in the labour market, and the opportunities for children to obtain the required skills and credentials are two important factors influencing the degree of generational mobility and the differences across countries. The post war social policy agenda with respect to equalizing opportunities has sought to reduce the significance of family connections in determining access to education and job opportunities, while at the same time increasing access to higher and higher levels of education. Generational mobility is associated with more per student spending on education if the underlying structure of the education system has a preference for those from the least advantaged backgrounds. Countries differ 
significantly in the impact that education spending has on generational mobility, and more spending could amplify rather then diminish the differences between advantaged and disadvantaged children. These differences have their roots in the more subtle advantages highly educated parents are able to pass on to their children: skills, beliefs and motivation arising from an advantaged family culture and parenting style. These non monetary factors determine the strength of the relationship between a child's cognitive skills in adulthood and their parents' education, which in turn is also associated with the degree of generational mobility in a society. Societies leveling these influences across the population display a higher degree of generational mobility.

This implies that thinking of the welfare state in the OECD countries as an institution that is 'enabling,' that in other words invests in children, is a perspective that attempts to shift the intergenerational relationship between parent and child incomes, and is likely to be more successful than a focus exclusively on the traditional view of the welfare state as a scheme for redistribution or social insurance. If this perspective is adopted recent research suggests the focus be put on facilitating early child development.

This is not to say that money is of no consequence. It is increasingly claimed that child poverty in economies of plenty should be no more tolerated than poverty among the elderly, the elimination of which has been one of the important accomplishments of the more progressive welfare states. This claim is often buttressed by the fact that children differ from other groups because current circumstances are important not just for their well-being in the present but also decades into the future. However, the capacity of children to become self-sufficient and successful adults is compromised not only by monetary poverty, but by poverty of experience, influence, and expectation. This 
argument calls for broader thinking on the mechanisms and causes of generational mobility, and will may draw public policy into areas of social and labour market policies that touch on the functioning of families. Money is of consequence, but it is not enough. 
Bibliography

Altonji, Joseph G. and Thomas A. Dunn (1991). "Relationships among the Family Incomes and Labor Market Outcomes of Relatives.” Research in Labor Economics. Vol. 12, 269-310.

Atkinson, A. B., A. K. Maynard, and C. G. Trinder (1983). Parents and Children: Incomes in Two Generations. London: Heinemann Educational Books.

Atkinson, Tony, Bea Cantillon, Eric Marlier, and Brian Nolan (2002). Social Indicators: The EU and Social Inclusion. Oxford: Oxford University Press.

Baker, Michael and Gary Solon (2003). "Earnings Dynamics and Inequality among Canadian Men, 1976-1992: Evidence from Longitudinal Income Tax Records.” Journal of Labor Economics. Vol. 21, 289-322.

Becker, Gary S. and Nigel Tomes (1979). "An Equilibrium Theory of the Distribution of Income and Intergenerational Mobility.” Journal of Political Economy. Vol. 87, pp. 1153-89.

Behrman, Jere and Paul Taubman (1990). "The Intergenerational Correlation Between Children's Adult Earnings and Their Parents' Income: Results from the Michigan Panel Survey of Income Dynamics” Review of Income and Wealth. Vol. 36, 115-27.

Behrman, Jere and Paul Taubman (1985). "Intergenerational Earnings Mobility in the United States: Some Estimates and a Test of Becker's Intergenerational Endowment's Model.” Review of Economics and Statistics. Vol. 67, 141-51.

Björklund, Anders, Bernt Bratsberg, Tor Eriksson, Markus Jäntti, Robin Naylor, Oddbjørn Raaum, Knut Roed, Eva Österbacka (2003). "Intergenerational earnings mobility in the Nordic countries and the United States: An overview." Preliminary draft.

Björklund, Anders and Markus Jäntti (1997). "Intergenerational Income Mobility in Sweden Compared to the United States.” American Economic Review. Vol. 87, 1009-18.

Blanden, Jo, Alissa Goodman, Paul Gregg and Stephen Machin (2004). "Changes in Intergenerational Mobility in Britain.” In Miles Corak (editor). Generational Income Mobility in North America and Europe. Cambridge: Cambridge University Press.

Bratberg, Espen, Øivind A. Nilsen, and Kjell Vaage (2003). “Assessing Changes in Intergenerational Earnings Mobility.” IZA Discussion Paper No. 797. 
Bruniaux, Christine and Bénédicte Galtier (2003). "L’étude du devenir des enfants de familles défavorisées : L’apport des experiences Américaine et Britannique.” Conseil de l'Emploi, des Revenus et de la Cohésion Sociale, Les Papiers du CERC No. 2003-01.

Buron, Laerence (1994). "A study of the magnitude and determinants of intergenerational earnings mobility.” PhD Dissertation, University of Wisconsin.

Checchi, Daniele, Andrea Ichino, and Aldo Rustichini (1999). "More equal but less mobile? Education financing and intergenerational mobility in Italy and the US." Journal of Public Economics. Vol. 74, 351-93.

Commission of the European Communities (2003). “Joint Report on Social Inclusion.” Brussels, 12.12.2003, COMM (2003) 773 final.

Comi, Simona (2003). "Intergenerational mobility in Europe: evidence from ECHP.” Università degli studi di Milano.

Corak, Miles (2005a). "Equality of opportunity and inequality across the generations: challenges ahead.” Policy Options/Options Politiques. Vol. 26, No. 03 (March/April), pp. 78-83.

Corak, Miles (2005b). "Inequality across the generations in North America and Europe." CESifo DICE Report, Journal for International Comparisons. Vol. 3, No. 4 (Winter), pp. 34-39.

Corak, Miles editor (2004a). Generational Income Mobility in North America and Europe. Cambridge: Cambridge University Press.

Corak, Miles (2004b). “Les enfants pauvres deviennent-ils des adultes pauvres? Les enseignements pour les politiques publiques d'une comparaison internationale.”Actes, Colloque “Le devenir des enfants de familles défavorisées en France” $1^{\text {er }}$ avril. Carré des Sciences, Ministère de la Jeunesse, de l’Éducation nationale et de la Recherche, Paris, France.

Corak, Miles (2001). “Are the Kids All Right: Intergenerational Mobility and Child WellBeing in Canada.”. In Keith Banting, Andrew Sharpe. and France St-Hilaire (editors). Review of Economic Performance and Social Progress. Montreal and Ottawa: Institute for Research on Public Policy and Centre for the Study of Living Standards.

Corak, Miles and Andrew Heisz (1999). “The Intergenerational Earnings and Income Mobility of Canadian Men: Evidence from Longitudinal Income Tax Data.” Journal of Human Resources. Vol. 34, pp. 504-33. 
Corak, Miles and Andrew Heisz (1998). "How to Get Ahead in Life: Some Correlates of Intergenerational Income Mobility in Canada.” In Miles Corak (editors), Labour Markets, Social Institutions, and the Future of Canada's Children. Ottawa: Statistics Canada, catalogue no. 89-553.

Couch, Kenneth A. and Thomas A. Dunn (1997). "Intergenerational Correlations in Labor Market Status: A Comparison of the United States and Germany.” Journal of Human Resources. Vol. 22, 210-32.

Couch, Kenneth A. and Dean R. Lillard (1998). "Sample Selection Rules and the Intergenerational Correlation of Earnings.” Labour Economics. Vol. 5, 313-29.

Creedy, John (1988). "Earnings Comparisons Between Generations: Some Alternative Approaches.” The Manchester School. Vol. 61, 268-81.

Dearden, Lorraine, Stephen Machin, and Howard Reed (1997). “Intergenerational Mobility in Britain.” Economic Journal. Vol. 107, 47-66.

Eide, Eric R. and Mark H. Showalter (1999). "Factors Affecting the Transmission of Earnings Across the Generations: A Quantile Regression Approach.” Journal of Human Resources. Vol. 34, 253-67.

Esping-Andersen, Gøsta (2004). "Unequal Opportunities and the Mechanisms of Social Inheritance.” In Miles Corak (editor). Generational Income Mobility in North America and Europe. Cambridge: Cambridge University Press.

Esping-Andersen, Gøsta (2002). Why we need a New Welfare State. Oxford: Oxford University Press.

Fortin, Nicole M. and Sophie Lefebvre (1998). "Intergenerational Income Mobility in Canada.” In Miles Corak (editor). Labour Markets, Social Institutions, and the Future of Canada's Children. Ottawa: Statistics Canada, Catalogue No. 89-553.

Grawe, Nathan D. (2004). "Intergenerational Mobility for Whom? The Experience of High and Low Earnings Sons in International Perspective.” In Miles Corak (editor). Generational Income Mobility in North America and Europe. Cambridge: Cambridge University Press.

Grawe, Nathan D. (2003). "Life cycle bias in the estimation of intergenerational earnings persistence.” Family and Labour Studies, Analytical Studies Branch Research Paper No. 207. Ottawa: Statistics Canada.

Gustafsson, Björn (1994). “The Degree and Pattern of Income Immobility in Sweden.” Review of Income and Wealth. Series 40, 67-86. 
Harding, David J., Christopher Jencks, Leonard M. Loopoo, and Susan E. Mayer (2004). "The Changing Effect of Family Background on the Incomes of American Adults." In Samuel Bowles, Herbert Gintis and Melissa Osborne (editors). Unequal Chances: Family Background and Economic Success. Princeton: Princeton University Press and Russell Sage.

Hertz, Tom (2004). "Rags, Riches and Race: The Intergenerational Economic Mobility of Black and White Families in the United States.” In Samuel Bowles, Herbert Gintis, and Melissa Osborne (editors). Unequal Chances: Family Background and Economic Success. Princeton: Princeton University Press and Russell Sage.

Hill, Martha S. and Greg J. Duncan (1987). "Parental Family Income and the Socioeconomic Attainment of Children.” Social Science Research. Vol. 16, 39-73.

Hyson, Rosemary (2003). "Differences in Intergenerational Mobility across the Earnings Distribution.” U.S. Bureau of Labor Statistics, Working Paper 364.

Jäntti, Markus and Eva Österbacka (2000). "How Much of the Variance in Income Can Be Attributed to Family Background? Empirical Evidence from Finland.” Abo Akademi University, Department of Economics and Statistics.

Jencks, Christopher (2004). "Should We Want a World in Which Family Background Doesn’t Matter?” Harvard University, Kennedy School of Government.

Jencks, Christopher and Laura Tach (2005). "Would Equal Opportunity Mean More Mobility?” Faculty Research Working Papers Series. Harvard University, John F. Kennedy School of Government.

Jenkins, Stephen (1987). "Snapshots versus Movies: 'Lifecycle Biases’ and the Estimation of Intergenerational Earnings Inheritance.” European Economic Review. Vol. 31, pp. 1149-58.

Keating, Daniel P. and Clyde Hertzman, editors (1999). Developmental Health and the Wealth of Nations: Social, Biological, and Educational Dynamics. New York: The Gilford Press.

Lefranc, Arnaud and Alain Trannoy (2003). "Intergenerational earnings mobility in France: an evaluation using data over three generations.” THEMA, Université de Cergy-Pontoise. Preliminary draft.

Lillard, Lee A. and Robert T. Reville (1996). "Intergenerational mobility in earnings and occupational status.” Unpublished.

Levine, David I. and Bhashkar Mazumder (2002). "Choosing the Right Parents: Changes in the Intergenerational Transmission of Inequality - Between 1980 and the Early 1990s.” Federal Reserve Bank of Chicago WP 2002-08. 
Lindahl, Lena (2002). "Do birth order and family size matter for intergenerational income mobility? Evidence from Sweden.” Swedish Institute for Social Research, Unpublished.

Mayer, Susan E. (2002). The Influence of Parental Income on Children's Outcomes. Ministry of Social Development, New Zealand.

Mayer, Susan E. (1997). What Money Can't Buy: Family Income and Children's Life Chances. Cambridge: Harvard University Press.

Mayer, Susan E. and Leonard M. Lopoo (2004). "What do Trends in the Intergenerational Economic Mobility of Sons and Daughters in the United States Mean?.” In Miles Corak (editor). Generational Income Mobility in North America and Europe. Cambridge: Cambridge University Press.

Mazumder, Bhashkar (2001). "Earnings Mobility in the US: A New Look at Intergenerational Inequality.” Department of Economics, University of California, Berkeley.

Minicozzi, Alexandra L. (1997). "Nonparametric analysis of intergenerational income mobility.” PhD Dissertation, University of Wisconsin.

Mocetti, Sauro (2006). “Intergenerational income mobility in Italy.” Unpublished paper, University of Bologna.

Mulligan, Casey B. (1997). Parental Priorities and Economic Inequality. Chicago: University of Chicago Press.

Österbacka, Eva (2003). “Mechanisms behind intergenerational earnings correlation in Finland 1985-1995.” Abo Akademi University, Department of Economics and Statistics.

Österbacka, Eva (2001). “Family Background and Economic Status in Finland.” Scandinavian Journal of Economics. Vol. 103, 467-84.

Österberg, Torun (2000). “Intergenerational Income Mobility in Sweden: What Do TaxData Show?” Review of Income and Wealth. Series 46, 421-36.

Page, Marianne E. (2004). "New Evidence on the Intergenerational Correlation in Welfare Participation.” In Miles Corak (editor). Generational Income Mobility in North America and Europe. Cambridge: Cambridge University Press.

Peters, Elizabeth H. (1992). "Patterns of Intergenerational Mobility in Income and Earnings.” Review of Economics and Statistics. Vol. 74, No. 3 pp.456-66. 
Reville, Robert T. (1995). "Intertemporal and Life Cycle Variation in Measured Intergenerational Earnings Mobility.” RAND Working Paper.

Roemer, John E. (2004). "Equal Opportunity and Intergenerational Mobility: Going Beyond Intergenerational Income Transition Matrices.” In Miles Corak (editor). Generational Income Mobility in North America and Europe. Cambridge: Cambridge University Press.

Sànchez Hugalde, Adriana (2004). "Movilidad intergeneracional de ingresos y educativea en Espana (1980-90).” Institut d'Economia de Barcelona, document de treball 2004/1.

Shea, John (2000). “Does Parents’ Money Matter?” Journal of Public Economics. Vol. $77,155-84$.

Solon, Gary (2004). “A Model of Intergenerational Mobility Variation over Time and Place.”In Miles Corak (editor). Generational Income Mobility in North America and Europe. Cambridge: Cambridge University Press.

Solon, Gary (2002). "Cross-Country Differences in Intergenerational Earnings Mobility.” Journal of Economic Perspectives. Vol. 16, 59-66.

Solon, Gary (1999). “Intergenerational Mobility in the Labor Market.” In Orley C. Ashenfelter and David Card (editors). Handbook of Labor Economics, Volume 3A. Amsterdam: Elsevier Science.

Solon, Gary (1992). "Intergenerational Income Mobility in the United States.” American Economic Review. Vol. 82, 393-408.

Solon, Gary (1989). "Biases in the Estimation of Intergenerational Earnings Correlations." Review of Economics and Statistics. Vol. 71, pp. 172-74.

Swift, Adam (2002). “Would Perfect Mobility be Perfect?” Department of Sociology, University of Oxford. Sociology Working Paper Number 2002-05.

UNICEF (2002). “A league table of educational disadvantage in rich nations.” Innocenti Report Card No. 4, UNICEF: Innocenti Research Centre, Florence.

Wiegrand, Johannes (1997). "Intergenerational Earnings Mobility in Germany.” Unpublished.

Zimmerman, David J. (1992). "Regression Toward Mediocrity in Economic Structure.” American Economic Review. Vol. 82, pp. 409-29. 


\section{Figure 1}

Within and cross-country variations in reported generational earnings elasticities for fathers and sons

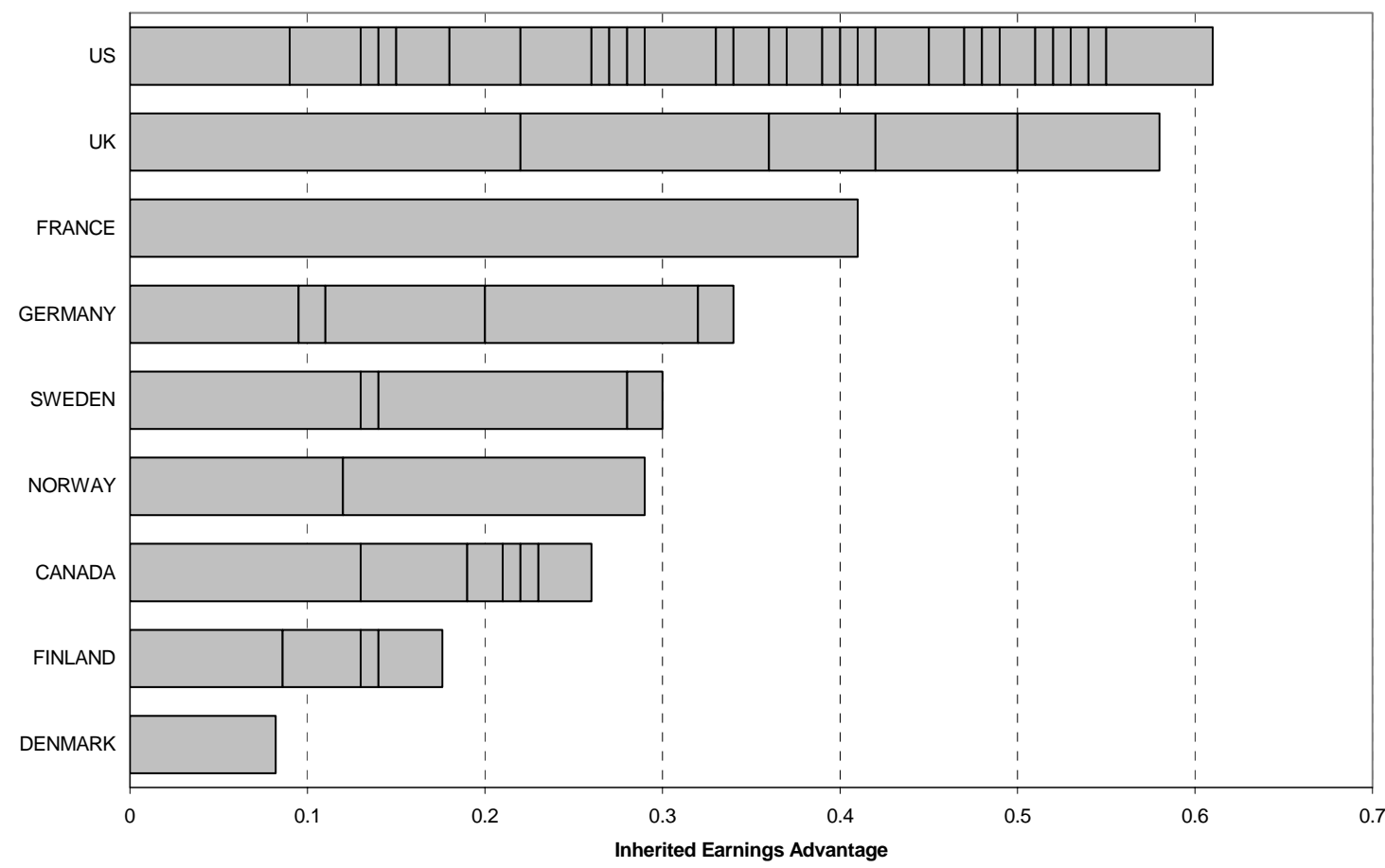

Note: each vertical bar represents the value of a reported earnings elasticity. For Denmark only one estimate is available, for the United States there are 28, the lowest is less than 0.1 and the highest slightly greater than 0.6.

Source: compiled from a literature survey by the author. See appendix. 
Figure 2

Variations in reported generational earnings elasticities in the United States for fathers and sons according to the average age of fathers used in the analysis

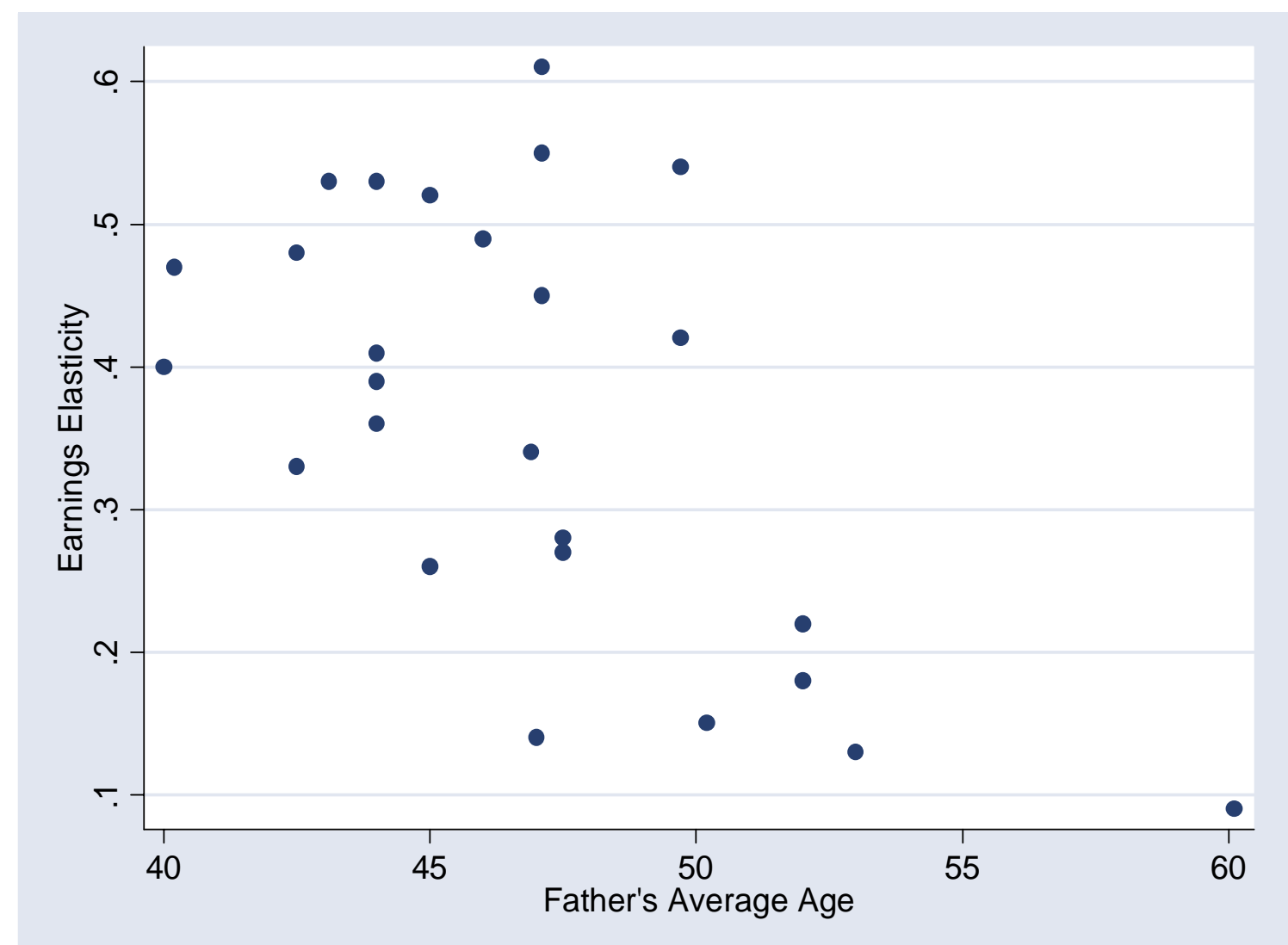

Source: Grawe (2004) and compilations by the author. See appendix. 


\section{Table 1}

Generational earnings elasticities for cross country comparisons

\begin{tabular}{lccc}
\hline \multicolumn{1}{c}{ Country } & \multicolumn{3}{c}{ Estimates for cross country comparisons } \\
\cline { 2 - 4 } & Preferred & Lower Bound & Upper Bound \\
\cline { 2 - 4 } & & & \\
\hline & & 0.13 & 0.16 \\
Denmark & 0.15 & 0.15 & 0.19 \\
Norway & 0.17 & 0.16 & 0.21 \\
Finland & 0.18 & 0.16 & 0.21 \\
Canada & 0.19 & 0.23 & 0.30 \\
Sweden & 0.27 & 0.27 & 0.45 \\
Germany & 0.32 & 0.35 & 0.52 \\
France & 0.41 & 0.40 & 0.55 \\
United States & 0.47 & 0.43 & \\
United Kingdom & 0.50 & & \\
\hline
\end{tabular}

Source: Compiled and calculated by the author. See appendix for details. 
Table 2

Generational earnings elasticities and their determinants

\begin{tabular}{lccc}
\hline \multicolumn{1}{c}{ Country } & $\begin{array}{c}\text { Father - Son earnings } \\
\text { elasticity }\end{array}$ & $\begin{array}{c}\text { Private internal rate of } \\
\text { return to tertiary } \\
\text { education (\%) }\end{array}$ & $\begin{array}{c}\text { Gradient between child } \\
\text { test score and parental } \\
\text { education }\end{array}$ \\
\hline Denmark & 0.15 & 7.9 & 4.4 \\
Norway & 0.17 & $\ldots$ & 6.1 \\
Finland & 0.18 & $\ldots$ & $\ldots$ \\
Canada & 0.19 & 8.4 & 5.1 \\
Sweden & 0.27 & 9.4 & 6.2 \\
Germany & 0.32 & 7.1 & $\ldots$ \\
France & 0.41 & 13.3 & 10.3 \\
United States & 0.47 & 18.9 & 11.3 \\
United Kingdom & 0.50 & 0.882 & 0.856 \\
Correlation with earnings elasticity & & & \\
\hline
\end{tabular}

... indicates not available.

Source: Father-Son earnings elasticities are compiled by the author as presented in Table 1. Private internal rate of return to tertiary education is from the OECD Education at a Glance, and refers to the rate of return for higher pre-tax earnings for men. It is calculated by comparing the costs and benefits of tertiary education with those of upper secondary education. The calculation is for 1999/2000. The gradient between child test scores and parental education is from Esping-Andersen (2004, table 1) and is derived by a least squares regression of test score results for 30 to 39 year old men (except for Canada which is based on 25 to 35 year olds) and father's education. The test scores are from the average individual scores of a comprehensive measure including document, prose and quantitative abilities. The estimates control for immigrant status. 
Figure 3

Cross country earnings elasticities for fathers and sons and the return to tertiary education

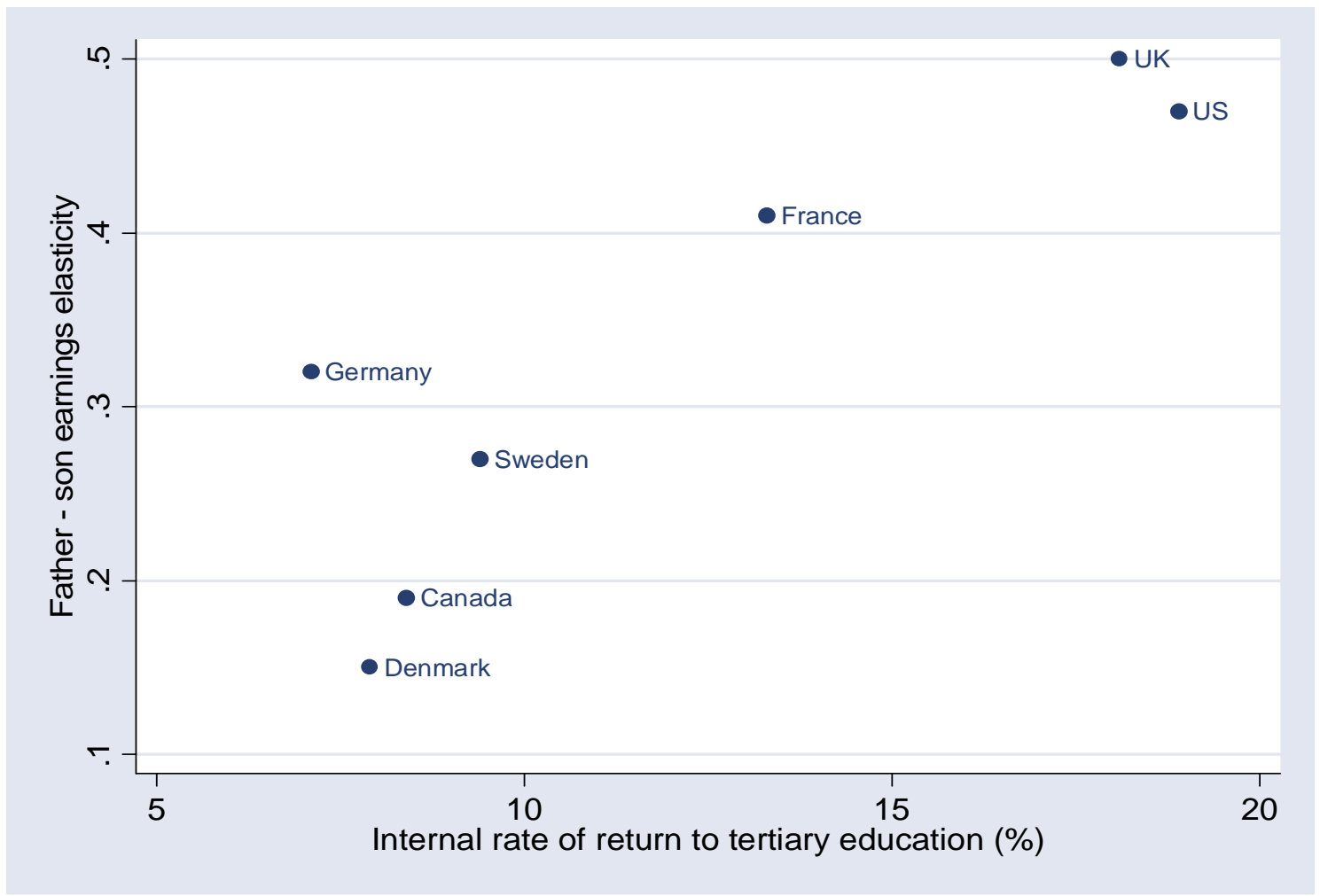

Source: Table 2. 
Figure 4

Cross country earnings elasticities for fathers and sons and the cognitive skills of children

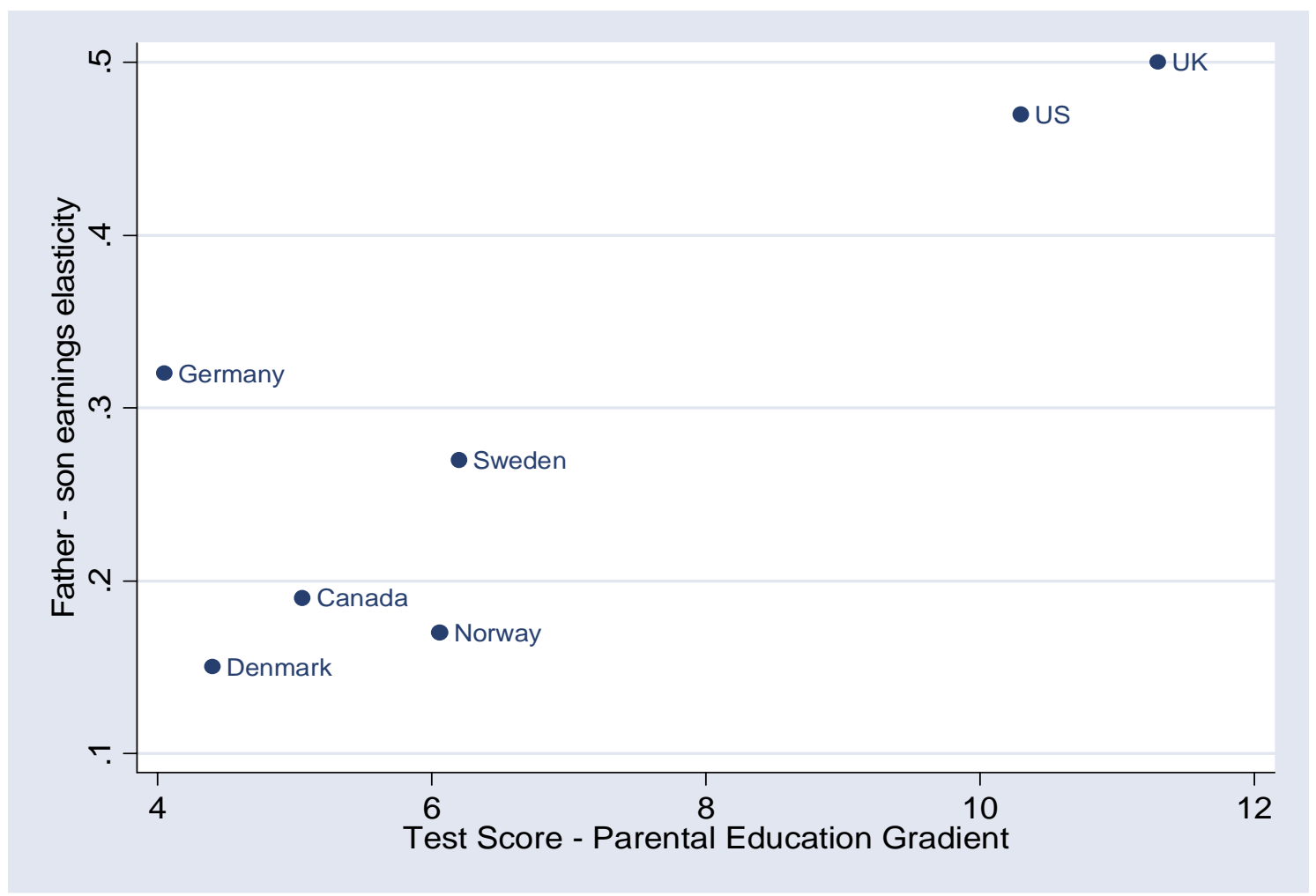

Source: Table 2 


\section{Figure 5}

A depiction of the impact of income transfer policies on generational mobility in a regression to the mean model

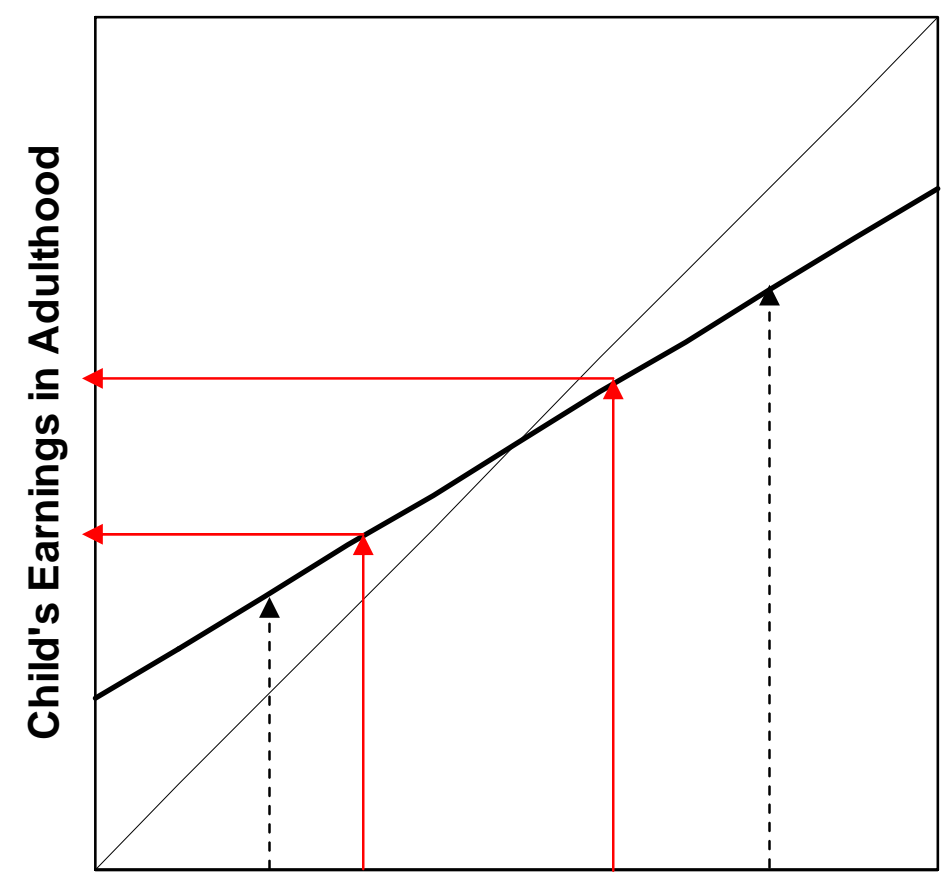

Parent's Earnings

Note: The boldface line represents the estimated equation $\ln Y_{i, t}=\alpha+\beta \ln Y_{i, t-1}+\varepsilon_{i, t}$ with the line from the origin representing the 45 degree line. Dashed arrows indicate earnings outcomes for a poor and a rich parent in the labour market. Post tax and transfer incomes are indicated by solid lines indicating that the income distribution is more equal in both the parents' generation and in the next generation. 
Figure 6

An alternative depiction of the impact of income transfer policies on generational mobility in a regression to the mean model with two subpopulations

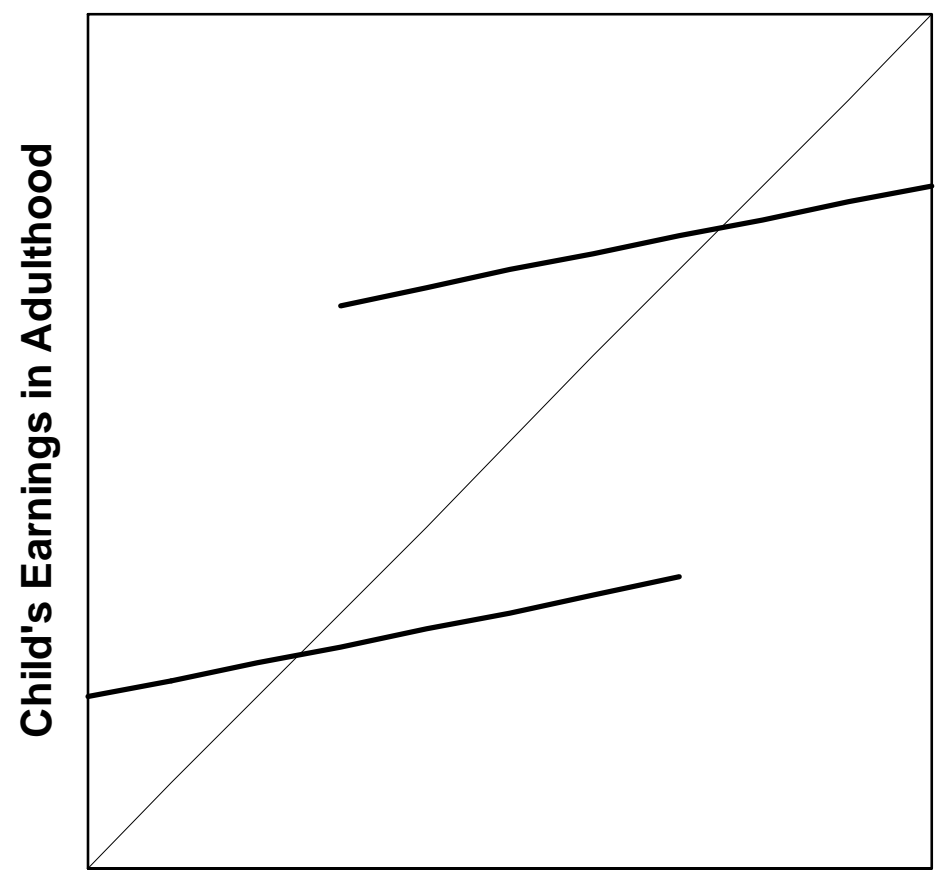

Parent's Earnings

Note: The two boldface line represents the estimated equation $\ln Y_{i, t}=\alpha+\beta \ln Y_{i, t-1}+\varepsilon_{i, t}$ for different values of $\alpha$, which characterize the value of an observed characteristic of two subpopulations. The line from the origin representing the 45 degree line. 


\section{Figure 7}

An interpretation of non linear patterns in earnings elasticities as resulting from a mixture of two types of families

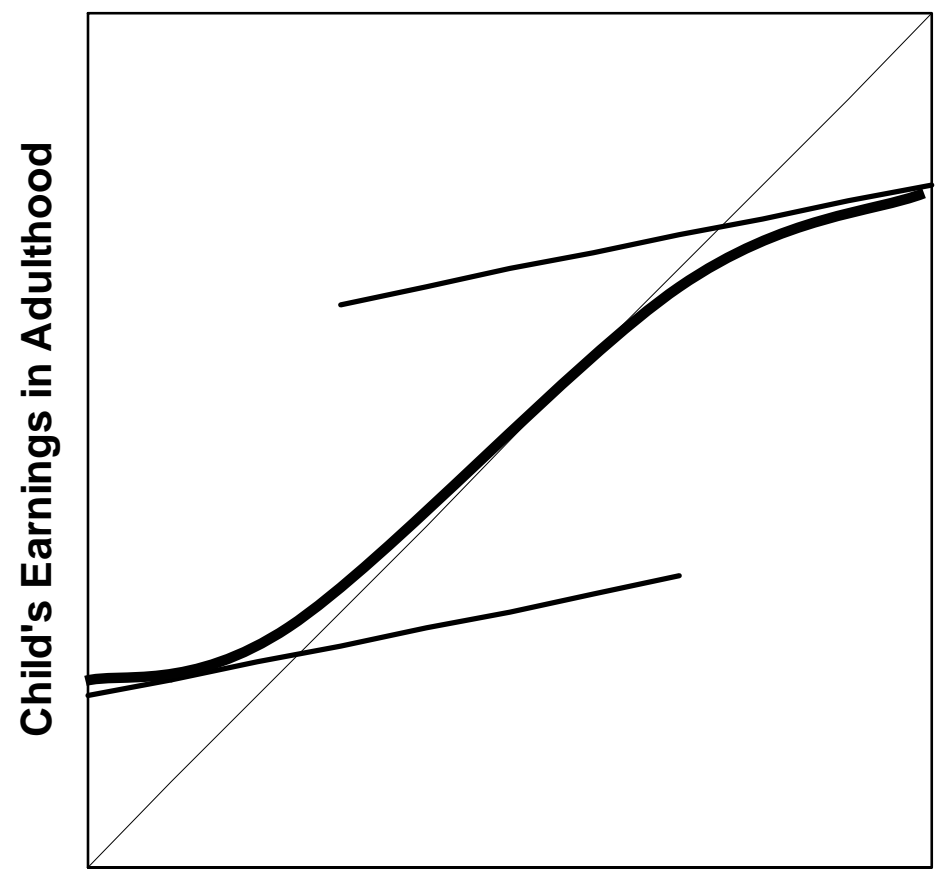

\section{Parent's Earnings}

Source: adapted from Corak and Heisz (1999) 
Figure 8

Cross country earnings elasticities for fathers and sons versus education spending per student

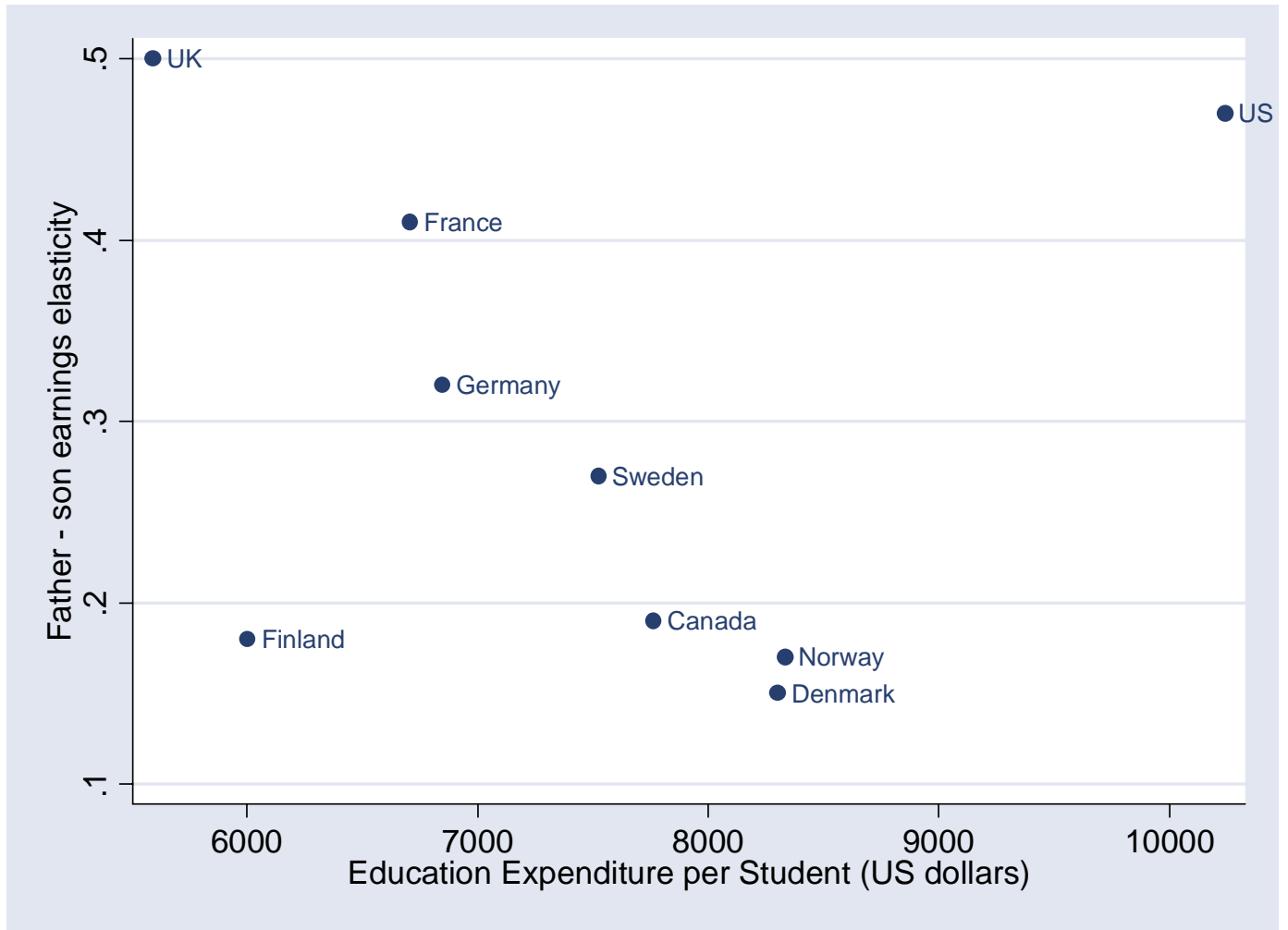

Source: Table 1 and OECD Education at a Glance. 
Appendix

The Derivation of generational earnings elasticities for cross-country comparisons

The preferred estimates of the generational earnings elasticities for fathers and sons depicted in Table 1 are derived in the following way. For each country a survey of all available estimates was made at the time this paper was begun in early 2004, including to the extent possible information needed to assess their reliability and comparability. These are reported in the following tables. This information includes the average ages of the sons and fathers when earnings are reported, and whether the correction for measurement error involves time averaging of fathers earnings with least squares (and if so the number of years used in the average) or instrumental variables. Other information was also collected: the data source, the year the son's outcomes are observed, sample selection rules, and any deviations from the use of father and son earnings as the regressor and/or regressand. On the basis of a review of this information an initial "best" available country estimate is highlighted. This reflects my understanding of the literature. With a couple of exceptions this "best" available estimate is used to determine the preferred estimate for cross country comparisons in one of two ways depending upon the country.

Grawe (2004) is used as the anchor to create comparable estimates for the United States, Canada, Germany and the United Kingdom. This study is the most recent and extensive to explicitly make cross-country comparisons in generational earnings elasticities. It extends the approach in Couch and Dunn (1997), who study the US and Germany, and Björklund and Jäntti (1997), who study the US and Sweden. Grawe examines the US (with both PSID and NLS data), Canada, Germany, and the United Kingdom by making a series of pair wise comparisons between the US and these countries using similar sample selection rules for each comparison. I use Grawe's US estimate of 0.473 from the PSID as a base case to anchor the comparisons. (The justification for adopting this result over the lower NLS estimate he reports is provided below in the review of the US literature.) The PSID estimate makes full use of the length of the panel, the longest internationally available. I scale the other country estimates by using the ratio of 0.473 to the particular US estimate derived from the sample selection rules for each pair of comparisons. For example, using similar ranges for father and son ages, and similar measurement error corrections Grawe (2004, table 4-3) reports an elasticity of 0.152 for Canada and 0.381 for the US. This Canadian estimate is scaled by $1.24(=0.473 / 0.381)$ to obtain an estimate of 0.19 for Canada in cross-country comparisons. The estimates in Table 1 for Germany and the United Kingdom are derived in a like manner.

The preferred estimates for the remaining countries are obtained following a meta analysis of the US literature. As described below least squares is used to estimate a model of the way in which reported earnings elasticities vary with father's age, the number of years of averaging to correct for measurement error, and an indicator of the use of instrumental variables. A predicted US elasticity is derived using values for the covariates set to those employed in the "best" available estimate from each country. This calculation assumes that the life cycle pattern of earnings is the same in all countries as that in the United States. The "best" estimate is then scaled using this prediction and a 
prediction for a 45 year old father in the US with 10 years to average earnings, which at 0.462 is similar to 0.473 reported by Grawe. For example, for Demark the best (and in this case the only) reported elasticity is 0.082 . The original authors obtain this from data in which fathers are on average 50 years of age and only one year of earnings is used in deriving a measure of permanent income. This is very likely an underestimate of the truth, and not appropriate for international comparisons. With these values as co-variates the predicted US elasticity is 0.260 , less than the 0.462 predicted when age is 45 and 10 years are used in the averaging. The "preferred" Danish estimate for cross-country comparisons is $0.15(=0.082[0.462 / 0.260])$. Estimates are derived for Finland, Norway, and Sweden in a similar way. The French estimate, however, is taken from the only study on the subject because the required information is not available to predict a comparable US estimate.

Upper and lower bound estimates are derived using a similar approach, but basing the US predictions on a 45 year old with five years of averaging as the lower bound, and with 15 years of averaging for the upper bound. For Canada, Germany and the UK the upper and lower bounds are scaled versions of the US bounds. To obtain the lower bound the preferred estimate is multiplied by the ratio of the US lower bound to the US preferred estimate: $0.40 / 0.47$. A similar scaling is used for the upper bound, which uses the ratio $0.52 / 0.47$. 


\section{United States}

\begin{tabular}{|c|c|c|c|c|c|c|c|}
\hline \multirow[t]{2}{*}{ Author } & \multirow[t]{2}{*}{$\begin{array}{l}\text { Earnings } \\
\text { Elasticity }\end{array}$} & \multirow{2}{*}{$\begin{array}{l}\text { Year of } \\
\text { Son's } \\
\text { Outcome }\end{array}$} & \multicolumn{2}{|c|}{$\begin{array}{l}\text { Average Age or } \\
\text { Range of Ages }\end{array}$} & \multicolumn{2}{|c|}{$\begin{array}{l}\text { Number of Years } \\
\text { Earnings Averaged }\end{array}$} & \multirow[t]{2}{*}{$\begin{array}{l}\text { Estimation } \\
\text { Method }\end{array}$} \\
\hline & & & Sons & Fathers & Sons & Fathers & \\
\hline Behrman Taubman (1985) & 0.09 & 1980 & 28 & 60.1 & & 1 & LS \\
\hline Couch Dunn (1997) & 0.13 & & 24.9 & 53 & & 6 & LS \\
\hline Levine Mazumder (2002) ${ }^{1}$ & 0.13 & 1980 & $28-36$ & & & & LS \\
\hline Peters $(1992)^{2}$ & 0.14 & & & 47 & & & LS \\
\hline Grawe $(2004)^{2}$ & 0.15 & 1980 & & 50.2 & & 4 & LS \\
\hline Altonji Dunn $(1991)^{2}$ & 0.18 & & $24-39$ & 52 & & 8 & LS \\
\hline Altonji Dunn $(1991)^{2}$ & 0.22 & & $24-39$ & 52 & & 0 & IV \\
\hline Levine Mazumder $(2002)^{12}$ & 0.22 & 1980 & $28-36$ & & & 3 & LS \\
\hline BBEJNRRÖ (2003) & 0.26 & & 40 & 45 & & 1 & LS \\
\hline Behrman Taubman $(1983)^{1}$ & 0.27 & & & $45-50$ & & & LS \\
\hline Lillard Reville (1996) & 0.28 & & $25-40$ & & & 3 & LS \\
\hline Tsai (1983) & 0.28 & & & $45-50 ?$ & & & LS \\
\hline Levine Mazumder (2002) ${ }^{1}$ & 0.29 & 1992 & $28-36$ & & & 3 & LS \\
\hline Mulligan (1997) & 0.33 & 1986 & $23-37$ & $40-45$ & & & LS \\
\hline Eide Showalter (1999) & 0.34 & & $24-40$ & & & 3 & LS \\
\hline Mazumder (2001) & 0.34 & 1997 & $27-35$ & $28-71$ & & 2 & LS \\
\hline Shea (2000) & 0.36 & & $25-40$ & 44 & & 12 & LS \\
\hline Couch Lillard (1998) & 0.37 & & $28-38$ & & & 4 & LS \\
\hline Björklund Jäntti (1997) & 0.39 & 1987 & $28-36$ & & & 5 & LS \\
\hline Buron (1994) & 0.39 & & $25-37$ & & & 5 & LS \\
\hline Solon (1992) & 0.39 & 1984 & $25-33$ & 44 & & 1 & LS \\
\hline Hyson (2003) & 0.40 & 1991 & 33 & 40 & & 5 & LS \\
\hline Levine Mazumder (2002) ${ }^{1}$ & 0.41 & 1993 & $28-36$ & & & 3 & LS \\
\hline Solon (1992) & 0.41 & 1984 & $25-33$ & 44 & & 5 & LS \\
\hline Björklund Jäntti (1997) & 0.42 & 1987 & & & & 5 & IV \\
\hline Minicozzi (1997) & 0.42 & & $28-29$ & & & & LS \\
\hline Zimmerman $(1992)^{2}$ & 0.42 & 1981 & $29-39$ & 49.7 & & 0 & IV \\
\hline Levine Mazumder $(2002)^{12}$ & 0.45 & 1980 & $28-36$ & & & 3 & LS \\
\hline Mazumder (2001) & 0.45 & 1997 & $30-35$ & $27-69$ & & 6 & LS \\
\hline Grawe (2004) & 0.47 & 1993 & $<46$ & 40.2 & & 5 & LS \\
\hline Mulligan (1997) & 0.48 & 1986 & $23-37$ & $40-45$ & & 0 & IV \\
\hline Reville (1995) & 0.48 & & $32-40$ & & & 5 & LS \\
\hline BBEJNRRÖ $(2003)^{2}$ & 0.49 & & 40 & 46 & & 1 & LS \\
\hline Levine Mazumder (2002) ${ }^{1}$ & 0.51 & 1992 & $28-36$ & & & & LS \\
\hline Björklund Jäntti (1997) & 0.52 & 1987 & $28-36$ & 45 & & 5 & IV \\
\hline Couch Lillard (1998) & 0.53 & & $25-33$ & & & 5 & LS \\
\hline Hertz (2004) & 0.53 & & $22-55$ & 43.1 & & 12 & LS \\
\hline Solon (1992) & 0.53 & 1984 & $25-33$ & 44 & & 0 & IV \\
\hline Zimmerman $(1992)^{2}$ & 0.54 & 1981 & $29-39$ & 49.7 & & 4 & LS \\
\hline Mazumder (2001) & 0.55 & 1997 & $30-35$ & $27-69$ & & 9 & LS \\
\hline Mazumder (2001) & 0.61 & 1997 & $30-35$ & $27-69$ & & 16 & LS \\
\hline
\end{tabular}

Boldface indicates preferred estimate for international comparisons.

- indicates not applicable, while blanks indicate information could not be discerned from the published report.

LS refers to least squares, IV refers to instrumental variables

1. Family income is used as the regressor.

2. Based on NLS data. 
The preferred estimate is 0.47 and the lower and upper bound are 0.40 and 0.52 .

While the US evidence is the most numerous, the sample sizes in the major data sets used - the PSID and the NLS — are very small, measuring only one or two hundred observations or even fewer. As a result this implies that sample selection rules used by researchers to develop their analytical files for estimation may have a major role to play in explaining the wide variation in results. Further, these two data sources consistently seem to yield different results. Studies based on the NLS have historically yielded lower elasticities than those based on the PSID. For example, the overall average of the elasticity in the 41 cited reports is 0.37 , the 10 estimates based upon the NLS yield an average of 0.31 but the 22 on the PSID average 0.40 . This tendency is in contrast with the findings of Solon (1992) and Zimmerman (1992), who report roughly similar results using respectively the PSID and the NLS. It has been claimed that this is due to the sample selection rules employed by Zimmerman that lead to a focus on workers with a strong labour market attachment. Zimmerman's justification for doing so has to do with minimizing measurement problems in deriving an estimate of permanent income. This pattern, however, also reflects the use of NLS 1980s data. When more recent NLS data are used, as in Levine and Mazumder (2002) and Björklund, Bratsburg, Ericksson, Jäntti, Naylor, Raaum, Roed, Österbacka (2003) for example, the pattern seems to reverse with NLS estimates being higher than PSID estimates. This has not been explained.

The smaller elasticities reported in the table, those of about 0.22 or less, are all based on samples of fathers whose average age tends to be 50 years or more, as a result they are likely underestimates for the reasons explained by Grawe (2004). Five of these eight studies are NLS based. In addition one of them is not based on an representative sample: Behrman and Taubman (1985) is the lowest reported estimate, but this is for a sample of whites who are from relatively better off families. Their estimate almost doubles to 0.17 when individuals with less than \$5,000 earnings are excluded.

To avoid difficulties of this sort Grawe (2004) adopts similar sample selection rules across countries for a comparative study but also between the NLS 1980 and the PSID. These two data sources yield very different results, 0.154 and 0.473 , and he suggests that it is difficult to take a definitive stand on which is correct without additional information on which data source is most appropriate.

Two factors tip the balance to the higher PSID based findings. First, Mazumder (2001) brings different, and in a sense better data, to bear on the issue. He uses SIPP information linked to administrative data. This implies more accurate earnings information for two reasons: the use of administrative sources rather than survey, and the possibility of averaging over longer periods of time to correct for transitory fluctuations. He is able to replicate earlier findings when averaging over short horizons, but his estimates rise to 0.45 with a six year average, to 0.55 with nine years, and to as high as 0.61 with 16 years.

The second consideration has to do with the fact that these studies are restricted to the father-son earnings relationship. The focus on fathers implicitly adopts a view that 
paternal earnings can be considered equivalent to total household resources. If in fact this is not the case because on the one hand maternal earnings or income are significant, or on the other because family disruption implies the absence of paternal resources, then it is likely that the elasticity estimate will be too low. The absence of a father may lead to sample selection decisions that eliminate the more disadvantaged from the sample. For these reasons some researchers have focused attention on the relationship between son's earnings and parental family income, particularly Levine and Mazumder (2002) and Hertz (2004). This leads to much larger sample sizes, thousands rather than one or two hundred. Behrman and Taubman (1990) is also framed in this way, but not listed in the table because the focus is on children and no results are reported separately for sons. In these cases the findings suggest higher elasticities. In fact Berhrman and Taubman (1990) offer an estimate of 0.80 for child earnings and parent incomes when averaged over 10 years, well above the 0.61 estimate of Mazumder (2002) recorded here.

For these reasons the Grawe (2004) PSID estimate is chosen as the preferred estimate for international comparisons. But a complementary approach to developing a preferred estimate involves a meta-analysis of the literature. A least squares regression of reported earnings elasticities against father's age, the number of years of father's earnings used in calculating average earnings, and whether the analysis is based on instrumental variables or not yields the following results using the 22 observations for which this information is available.

\begin{tabular}{|c|c|c|c|c|c|c|}
\hline elasticity $=$ & constant & $+\beta_{1}$ father's age & \multicolumn{2}{|c|}{$+\beta_{2}$ years of average } & \multicolumn{2}{|c|}{$+\beta_{3}$ instrumental variables } \\
\hline $\begin{array}{l}\text { coefficient } \\
\text { t statistic } \\
\mathrm{P}>|\mathrm{t}|\end{array}$ & $\begin{array}{l}1.21 \\
4.59 \\
0.00\end{array}$ & $\begin{array}{c}-0.0192 \\
-3.57 \\
0.002\end{array}$ & & & & \\
\hline \multicolumn{7}{|c|}{$\begin{array}{l}\text { For a number of reasonable specifications these results imply the following predicted } \\
\text { elasticities. }\end{array}$} \\
\hline & (1) & (2) & (3) & (4) & Grawe & Mazumder \\
\hline father's age & 45 & 45 & 45 & 45 & 40.2 & 47.1 \\
\hline years of average & 0 & 5 & 10 & 15 & 5 & 16 \\
\hline instrumental variables & 1 & 0 & 0 & 0 & 0 & 0 \\
\hline predicted elasticity & 0.454 & 0.404 & 0.462 & 0.521 & 0.496 & 0.493 \\
\hline
\end{tabular}

The preferred estimate of 0.47 is in the range of these results, corresponding roughly either to an analysis based upon a 45 year old father and employing either instrumental variables or averaging earnings over 10 years. The specifications in Grawe's study would 
actually predict a higher elasticity than he obtained ( 0.496 versus 0.473$)$, while those of Mazumder yielding the 0.61 estimate would predict a lower.

On this basis a preferred elasticity of 0.47 is not an unreasonable summary of the existing findings for the United States that takes into account some of the factors that may cause the estimates to differ. It might also be suggested that the upper and lower bounds of this estimate be set respectively at 0.40 and 0.52 , corresponding to the use of five and 15 years of averaging to correct for the measurement error in the permanent income of a 45 year old.

As described in the previous section this model is also used to adjust some of the estimates from other countries in order to make them comparable to a US base case illustrated in column (3), and to establish the lower and upper bounds for all countries. 


\section{Canada}

\begin{tabular}{lccccccc}
\hline Author & $\begin{array}{c}\text { Earnings } \\
\text { Elasticity }\end{array}$ & $\begin{array}{c}\text { Year of } \\
\text { Son’s } \\
\text { Outcome }\end{array}$ & $\begin{array}{c}\text { Average Age or } \\
\text { Range of Ages }\end{array}$ & $\begin{array}{c}\text { Number of Years } \\
\text { Earnings Averaged }\end{array}$ & $\begin{array}{c}\text { Estimation } \\
\text { Method }\end{array}$ \\
& & & Sons & Fathers & Sons & Fathers & \\
\hline Corak Heisz (1999) & 0.13 & 1995 & $29-32$ & 42.5 & 1 & 5 & LS \\
Grawe (2004) & 0.15 & 1996 & & & 1 & 5 & LS \\
Grawe (2004) & $\mathbf{0 . 1 9}$ & 1996 & & & - & - & generated \\
Corak (2001) & 0.21 & 1998 & $32-35$ & 45.5 & 1 & 5 & LS \\
Fortin Lefebvre (1998) & 0.22 & 1994 & 37.4 & & 0 & 0 & IV \\
Corak Heisz (1999) & 0.23 & 1995 & $29-32$ & 42.5 & 1 & 5 & LS \\
Corak (2001) & 0.26 & 1998 & $32-35$ & & 1 & 5 & LS \\
\hline
\end{tabular}

Boldface indicates preferred estimate for international comparisons.

- indicates not applicable, while blanks indicates information could not be discerned from the published report.

LS refers to least squares, IV refers to instrumental variables

1. Earnings elasticity is generated by scaling the estimated coefficient of 0.152 by $(0.473 / 0.381)$, the ratio of best US PSID estimate to comparable US PSID estimate.

The preferred estimate is 0.19 and the lower and upper bound are 0.16 and 0.21.

Corak and Heisz (1999, table 3) report an estimate of 0.13 based upon a sample in which father's earnings are required to on average be greater than $\$ 1$ over a five year period. This implies that some individuals with no or negative earnings in any number of years are included in the analysis. The same study reports an estimate of 0.23 when fathers are required to have at least one dollar of earnings in each of five successive years. The 0.26 result reported in Corak (2001) may be an overstatement because the earnings of both parents are used as the regressor rather than solely father's earnings, the same study reporting an estimate of 0.21 when the later is the case. This estimate, along with that of Fortin and Lefebvre (1998), may be the most reliable because the average age of the sons is highest. These two studies control for measurement error in different ways but reach essentially the same conclusion, an estimate that is not much higher than that generated from Grawe (2004). As a result the latter is used for the purposes of cross-country comparison, but a permissible range from the literature could by from 0.19 to 0.23 . It may be that this slightly understates the truth since all of the studies are based on sons younger than 40 years. On the other hand this may not be the case since Fortin and Lefebvre (1998) use instrumental variables, and is likely to overstate the truth for sons who are in fact close to 40 years of age. Using fathers age of 42.5 and five years of averaging, the parameters of Corak (1999), in the predicted model of the US literature would lead the estimated elasticity of 0.23 to be adjusted upward slightly to 0.24 .

The lower and upper bounds are obtained by using the preferred estimate of 0.19 and scaling it using the lower and upper bounds of the US relative to the preferred US estimate, that is $0.40 / 0.47$ and $0.52 / 0.47$. 


\section{Denmark}

\begin{tabular}{|c|c|c|c|c|c|c|c|}
\hline \multirow[t]{2}{*}{ Author } & \multirow[t]{2}{*}{$\begin{array}{l}\text { Earnings } \\
\text { Elasticity }\end{array}$} & \multirow{2}{*}{$\begin{array}{l}\text { Year of } \\
\text { Son's } \\
\text { Outcome }\end{array}$} & \multicolumn{2}{|c|}{$\begin{array}{l}\text { Average Age or } \\
\text { Range of Ages }\end{array}$} & \multicolumn{2}{|c|}{$\begin{array}{l}\text { Number of Years } \\
\text { Earnings Averaged }\end{array}$} & \multirow[t]{2}{*}{$\begin{array}{c}\text { Estimation } \\
\text { Method }\end{array}$} \\
\hline & & & Sons & Fathers & Sons & Fathers & \\
\hline $\begin{array}{l}\text { Björklund, Bratsburg, } \\
\text { Ericksson, Jäntti, } \\
\text { Naylor, Raaum, Roed, } \\
\text { Österbacka (2003) }\end{array}$ & 0.082 & 1997 & 40 & 50 & 1 & 1 & LS \\
\hline
\end{tabular}

LS refers to least squares

The preferred estimate is 0.15 and the lower and upper bound are 0.13 and 0.16 .

The only available estimate is 0.082 , but this is very likely to be an understatement since only one observation for father's earnings is used and on average fathers are 50 years old. If the ratio of variances in transitory to permanent incomes were in the order of 1.4 to 1.8, as reported in the US or Canada by Solon (1989) and Baker and Solon (2003), then the true estimate corrected for measurement error could be in the order of 0.12 to 0.15 . It is unlikely that 0.082 is even an accurate lower bound and an arbitrary scaling up of this sort would require information on the variance of transitory earnings fluctuations in Denmark.

Using an average age for fathers of 50 and one year of earnings averaging in the least squares model derived from the US meta analysis would imply an adjusted elasticity for Denmark of 0.15, with a lower bound of 0.13 and an upper bound of 0.16 . 


\section{Finland}

\begin{tabular}{llcccccc}
\hline Author & $\begin{array}{c}\text { Earnings } \\
\text { Elasticity }\end{array}$ & $\begin{array}{c}\text { Year of } \\
\text { Son's } \\
\text { Outcome }\end{array}$ & $\begin{array}{c}\text { Average Age or } \\
\text { Range of Ages }\end{array}$ & $\begin{array}{c}\text { Number of Years } \\
\text { Earnings Averaged }\end{array}$ & $\begin{array}{c}\text { Estimation } \\
\text { Method }\end{array}$ \\
& & & Sons & Fathers & Sons & Fathers & \\
\hline Österbacka (2003) & 0.086 & 1995 & 30.2 & 45.8 & 1 & 5 & LS \\
Österbacka (2001) & 0.13 & 1990 & 34.9 & 46 & 1 & 2 & LS \\
BBEJNRRÖ (2003) & 0.14 & 1999 & 40 & 44 & 1 & 1 & LS \\
Jäntti Österbacka (2000) & 0.14 & 1995 & 39.7 & 45.7 & 1 & 2 & LS \\
Jäntti Österbacka (2000) & 0.18 & 1990 & 39.7 & 45.7 & 3 & 2 & LS \\
\hline
\end{tabular}

LS refers to least squares

BBEJNRRÖ (2003) refers to Björklund, Bratsburg, Ericksson, Jäntti, Naylor, Raaum, Roed, Österbacka (2003)

The preferred estimate is 0.18 and the lower and upper bound are 0.16 and 0.21 .

All of the studies are comparable with respect to the average age of fathers, but Österbacka (2003) is noticeably lower probably because of the use of a younger set of sons. The age ranges of both the sons and fathers used in the latter three studies makes these the most reliable. The estimate of 0.18 offered by Jäntti and Österbacka (2000) is likely most reliable because sons earnings are also averaged, though there may be some question as to whether only two years of averaging of the fathers data is sufficient.

For the purposes of international comparisons the 0.14 estimate of BBEJNRRÖ (2003) and of Jäntti and Österbacka (2000) rather than 0.18 is used since the US literature is not for the most part based on studies that average the son's earnings. With 0.14 as a base case elasticity and with the parameters of 45.7 years and two years of averaging the least squares model from the US meta analysis predicts an adjusted Finnish elasticity of 0.18, as well as a lower and upper bound of 0.16 and 0.21 . (If 44 years and one year of averaging, as in BBEJNRRÖ, were used these results would be $0.17,0.15$, and 0.19.) 


\section{France}

\begin{tabular}{lccccccc}
\hline Author & $\begin{array}{c}\text { Earnings } \\
\text { Elasticity }\end{array}$ & $\begin{array}{c}\text { Year of } \\
\text { Son's } \\
\text { Outcome }\end{array}$ & $\begin{array}{c}\text { Average Age or } \\
\text { Range of Ages } \\
\text { Sons }\end{array}$ & $\begin{array}{c}\text { Fathers } \\
\text { Earnings Aver }\end{array}$ & Sons & Fathers & \\
\hline Lefranc Trannoy (2003) & $\mathbf{0 . 4 1}$ & 1993 & $30-40$ & $55-70$ & - & - & IV \\
\hline
\end{tabular}

Boldface indicates preferred estimate.

- indicates not applicable, while blanks indicates information could not be discerned from the published report.

IV refers to instrumental variables

The preferred estimate is 0.41 and the lower and upper bound are 0.35 and 0.45 .

The use of fathers between 55 and 70 implies a rather older sample and would lead to an understatement of the true elasticity. Indeed the use of somewhat younger fathers reported in panel A for 1993 in Table 1 of the study suggests slightly higher estimates, 0.44 . However the use of IV implies an over estimate. The study reports that the results also tend to vary when 1985 and 1977 outcomes are examined, being slightly lower but this is not conclusive.

There is no basis for developing an adjusted coefficient from the US meta analysis with these data. It is not clear what the average age of the fathers would be, and given the age range it is likely to be older than anything used in the regression analysis of the US literature. This would lead to a forecasting outside of the range of these data.

The preferred estimate is taken from the original study, which also reports several other results for differing time periods and samples. These are the basis for selecting the lower and upper bound. 


\section{Germany}

\begin{tabular}{lccccccc}
\hline Author & $\begin{array}{c}\text { Earnings } \\
\text { Elasticity }\end{array}$ & $\begin{array}{c}\text { Year of } \\
\text { Son's } \\
\text { Outcome }\end{array}$ & $\begin{array}{c}\text { Average Age or } \\
\text { Range of Ages }\end{array}$ & $\begin{array}{c}\text { Number of Years } \\
\text { Earnings Averaged }\end{array}$ & $\begin{array}{c}\text { Estimation } \\
\text { Method }\end{array}$ \\
& & & Sons & Fathers & Sons & Fathers & \\
\hline Grawe (2004) & 0.095 & 1997 & - & 47.5 & 1 & 5 & LS \\
Couch Dunn (1997) & 0.11 & - & 22.8 & 51 & 1 & 6 & LS \\
Wiegand (1997) & 0.20 & - & - & 51 & 1 & - & LS \\
Grawe (2004) & $\mathbf{0 . 3 2}$ & 1997 & - & & - & - & generated \\
Wiegand (1997) & 0.34 & - & - & & 1 & 5 & - \\
\hline
\end{tabular}

Boldface indicates preferred estimate.

- indicates not applicable, while blanks indicates information could not be discerned from the published report.

LS refers to least squares, IV refers to instrumental variables.

1.Earnings elasticity is generated by scaling the estimated coefficient of 0.095 by $(0.473 / 0.140)$, the ratio of best US PSID estimate to comparable US PSID estimate.

The preferred estimate is 0.32 and the lower and upper bound are 0.27 and 0.35 .

The GSOEP is being used to study intergenerational mobility but the sample of sons is still relatively young, leading to rather low estimates. This is clear from studies such as Couch and Dunn (1997) and Grawe (2004). Both use US PSID data defined along sample selection criteria similar to those used with the German data and obtain US elasticities much lower than those normally found using the PSID when an older group of sons is analysed. The scaled estimate by Grawe is similar to that of Weigand and is used as the preferred estimate. The upper and lower bounds are similarly scaled versions of this estimate using the preferred information from the US in a manner described for the Canadian data. 


\section{Norway}

\begin{tabular}{lccccccc}
\hline Author & $\begin{array}{c}\text { Earnings } \\
\text { Elasticity }\end{array}$ & $\begin{array}{c}\text { Year of } \\
\text { Son's } \\
\text { Outcome }\end{array}$ & $\begin{array}{c}\text { Average Age or } \\
\text { Range of Ages }\end{array}$ & $\begin{array}{c}\text { Number of Years } \\
\text { Earnings Averaged }\end{array}$ & $\begin{array}{c}\text { Estimation } \\
\text { Method }\end{array}$ \\
& Sons & Fathers & Sons & Fathers & \\
\hline Bratberg Nilsen and & 0.12 & 1992 & $30-34$ & 48 & 1 & 3 & LS \\
$\begin{array}{l}\text { Vaage (2003) } \\
\text { BBEJNRRÖ (2003) }\end{array}$ & 0.29 & 1999 & 40 & 44 & 1 & 1 & LS \\
\hline
\end{tabular}

- indicates not applicable, while blanks indicates information could not be discerned from the published report.

LS refers to least squares

BBEJNRRÖ (2003) refers to Björklund, Bratsburg, Ericksson, Jäntti, Naylor, Raaum, Roed, Österbacka (2003)

The preferred estimate is 0.17 and the lower and upper bound are 0.15 and 0.19 .

There is little to choose between the two available estimates. The first estimate averages father's earnings over three years, but the second uses an older set of sons. The first estimate is preferred for comparisons with other countries since the son's age corresponds more closely to that used in US studies and this variable is not one otherwise controlled for in the meta analysis of the US literature.

With a father's average age of 48 and three years of earnings averaging the US meta analysis suggests scaling the 0.12 estimate up to 0.17 , and leads to a lower and upper bound of 0.15 and 0.19 . All of these are within the reported range of published results. 
8. Sweden

\begin{tabular}{lccccccc}
\hline Author & $\begin{array}{c}\text { Earnings } \\
\text { Elasticity }\end{array}$ & $\begin{array}{c}\text { Year of } \\
\text { Son's } \\
\text { Outcome }\end{array}$ & $\begin{array}{c}\text { Average Age or } \\
\text { Range of Ages }\end{array}$ & $\begin{array}{c}\text { Number of Years } \\
\text { Earnings Averaged }\end{array}$ & $\begin{array}{c}\text { Estimation } \\
\text { Method }\end{array}$ \\
& & & Sons & Fathers & Sons & Fathers & \\
\hline Osterberg (2000) & 0.13 & 1992 & $25-51$ & 52 & 1 & 3 & LS \\
Gustafsson (1994) & 0.14 & - & $31-41$ & & 1 & 1 & LS \\
Björklund Jäntti (1997) & 0.28 & 1991 & $30-39$ & 43.3 & 0 & 0 & IV \\
Lindahl (2002) & 0.30 & 1999 & $35-37$ & 42 & 1 & 3 & LS \\
\hline
\end{tabular}

- indicates not applicable, while blanks indicates information could not be discerned from the published report.

LS refers to least squares, IV refers to instrumental variables

The preferred estimate is 0.27 and the lower and upper bound are 0.23 and 0.30 .

Osterberg (2000) uses a slightly older set of fathers and is likely to understate the true elasticity, while Gustafsson (1994) is based upon data from one city and may not be entirely representative. Also this is likely an underestimate by virtue of the use of only one year of father's data. There is little to choose between the remaining two studies, and Björklund and Jäntti (1997) is preferred because of the wider range of sons ages. The US meta analysis based on 43.3 years for fathers age and the use of instrumental variables would imply that the 0.28 elasticity be scaled down slightly to 0.27 with upper and lower bounds of 0.23 and 0.30 . If the parameters of the Lindahl (2002) were used (42 years and 3 years) the results would be higher: $0.32,0.28$ and 0.36 . 


\section{United Kingdom}

\begin{tabular}{|c|c|c|c|c|c|c|c|}
\hline \multirow[t]{2}{*}{ Author } & \multirow[t]{2}{*}{$\begin{array}{l}\text { Earnings } \\
\text { Elasticity }\end{array}$} & \multirow{2}{*}{$\begin{array}{l}\text { Year of } \\
\text { Son's } \\
\text { Outcome }\end{array}$} & \multicolumn{2}{|c|}{$\begin{array}{l}\text { Average Age or } \\
\text { Range of Ages }\end{array}$} & \multicolumn{2}{|c|}{$\begin{array}{l}\text { Number of Years } \\
\text { Earnings Averaged }\end{array}$} & \multirow[t]{2}{*}{$\begin{array}{c}\text { Estimation } \\
\text { Method }\end{array}$} \\
\hline & & & Sons & Fathers & Sons & Fathers & \\
\hline Dearden Machin Reed (1997) & 0.22 & & 33 & 47.5 & 1 & & LS \\
\hline $\begin{array}{l}\text { Atkinson, Maynard, Trinder } \\
\text { (1983) }\end{array}$ & 0.36 & & & & 1 & & LS \\
\hline $\begin{array}{l}\text { Atkinson, Maynard, Trinder } \\
\text { (1983) }\end{array}$ & 0.42 & & & & & & LS \\
\hline Grawe $(2004)^{1}$ & 0.50 & 1991 & - & - & - & - & generated \\
\hline Dearden Machin Reed (1997) & 0.58 & & 33 & 47.5 & - & - & IV \\
\hline Grawe (2004) & 0.58 & 1991 & 33 & & - & - & IV \\
\hline
\end{tabular}

Boldface indicates preferred estimate.

- indicates not applicable, while blanks indicates information could not be discerned from the published report.

LS refers to least squares, IV refers to instrumental variables

AMT (1983) refers to Atkinson, Maynard, Trinder (1983).

1. Earnings elasticity is generated by scaling the estimated coefficient of 0.579 by $(0.473 / 0.549)$, the ratio of best US PSID estimate to comparable US PSID estimate.

The preferred estimate is 0.50 and the lower and upper bound are 0.43 and 0.55 .

Atkinson, Maynard, Trinder (1983) is based on data for one city. The preferred estimate is the scaled Grawe (2004) estimate. This is lower than the 0.58 reported in the original analysis and in the study by Dearden Machin Reed (1997). The lower and upper bounds are derived in the same manner as for Canada and Germany, using the preferred estimates from the US by Grawe (2004). 


\section{Other Countries}

It should be noted that the results in the study by Comi (2003) are not reported in the literature review undertaken in spite of the fact that it explicitly undertakes a comparative analysis of intergenerational earnings mobility in Europe, analyzing 11 countries with the European Community Household Panel. When comparisons are possible the results of this study are very much lower than the existing literature. This is likely because the children used in the analysis sample are very young, averaging between 20.5 years in Denmark to a maximum of 24.3 in Belgium.

Mocetti (2006) offers an estimate of 0.55 to 0.84 for Italy using split sample IV methods. But this study came to my attention only after all the substantive work on this paper was completed, and it would appear to include all sources of income, not just earnings.

Sànchez Hugalde (2004) offers estimates for Spain that are based both on least squares and IV estimation ranging from 0.21 to 0.44 but the measures of earnings for fathers and sons seems to be taken in the same year and requires sons to be co-resident with fathers. 